\title{
Exhumation of high-pressure rocks beneath the Solund Basin, Western Gneiss Region of Norway
}

\author{
B. R. HACKER, ${ }^{1}$ T. B. ANDERSEN, ${ }^{2}$ D. B. ROOT, ${ }^{1}$ L. MEHL, ${ }^{1}$ J. M. MATTINSON ${ }^{1}$ \\ AND J.L. WOODEN ${ }^{3}$ \\ ${ }^{1}$ Department of Geological Sciences, University of California, Santa Barbara, CA 93106-9630, USA \\ (hacker@geology.ucsb.edu) \\ ${ }^{2}$ Department of Geology, University of Oslo, PO Box 1047 Blindern 0316, Oslo, Norway \\ ${ }^{3}$ U.S. Geological Survey, Menlo Park, CA 94025, USA
}

\begin{abstract}
The Solund-Hyllestad-Lavik area affords an excellent opportunity to understand the ultrahigh-pressure Scandian orogeny because it contains a near-complete record of ophiolite emplacement, high-pressure metamorphism and large-scale extension. In this area, the Upper Allochthon was intruded by the c. 434 Ma Sogneskollen granodiorite and thrust eastward over the Middle/Lower Allochthon, probably in the Wenlockian. The Middle/Lower Allochthon was subducted to c. $50 \mathrm{~km}$ depth and the structurally lower Western Gneiss Complex was subducted to eclogite facies conditions at $c .80 \mathrm{~km}$ depth by c. 410-400 Ma. Within < 5-10 Myr, all these units were exhumed by the Nordfjord-Sogn detachment zone, producing shear strains $>100$. Exhumation to upper crustal levels was complete by c. $403 \mathrm{Ma}$. The Solund fault produced the last few $\mathrm{km}$ of tectonic exhumation, bringing the nearultrahigh-pressure rocks to within $c .3 \mathrm{~km}$ vertical distance from the low-grade Solund Conglomerate.
\end{abstract}

Key words: eclogite; exhumation; Norway; Solund; ultrahigh pressure.

\section{INTRODUCTION}

The Norwegian Caledonides are one of the best places to study the exhumation of high-pressure (HP) and ultrahigh-pressure (UHP) rocks because of excellent exposure across the vast Western Gneiss Region (WGR), which contains spectacular coesite-bearing eclogites, garnet peridotites, and coesite- and diamondbearing gneisses (Cuthbert et al., 2000; Wain et al., 2000) (Fig. 1). Salient incompletely answered questions about the Norwegian Caledonian UHP rocks include the following.

(1) How and when did the HP-UHP metamorphism occur? Was there more than one HP or UHP event? Was it the result of an arc-continent or continentcontinent collision? For many years, the palaeomagnetic record of collision at c. $425 \mathrm{Ma}$ (Torsvik, 1998), the pioneering $\mathrm{Sm} / \mathrm{Nd}$ geochronology that dated HP metamorphism at $425 \mathrm{Ma}$ (Griffin \& Brueckner, 1980), and the stratigraphic record on the island of Atløy implying ophiolite emplacement in the Wenlockian (Andersen et al., 1990), were interpreted as indicating that the UHP metamorphism occurred during a continental collision. The subsequent realization that the age of the UHP event is 410-400 Ma (Tucker, in Lutro et al., 1997; Mearns, 1986; Mørk \& Mearns, 1986; Terry et al., 2000) indicates that the orogeny spanning collision and HP-UHP metamorphism may have lasted for 25 Myr. Moreover, the material emplaced onto the Caledonian margin of Baltica includes not only telescoped continental margin rocks, but also ophiolites, outboard Baltica crystalline and sedimentary rocks, and Laurentian continental rocks. Constraining the time that these various units were emplaced relative to the time of UHP metamorphism is still an important issue.

(2) How did the exhumation occur? Was it syncollisional or post-collisional? Did the subducted plate simply roll back as a semirigid sheet, did it rise buoyantly through the upper plate, or was it thrust onto the Baltica margin accompanied by higher-level extension? A significant part of the exhumation of the HP-UHP rocks can be attributed to an array of regionally extensive normal faults and extensional detachments, of which the Nordfjord-Sogn detachment zone (NSDZ) is the most important (Andersen \& Jamtveit, 1990). The NSDZ is a Caledonian amphibolite- to greenschist facies shear zone commonly capped by younger brittle faults that were reactivated in the Permian and Late Jurassic (Eide et al., 1997; Norton, 1986). The age of the ductile shearing is not well known because, despite concerted ${ }^{40} \mathrm{Ar} /{ }^{39} \mathrm{Ar}$ dating (e.g. Andersen, 1998), most of the movement on the ductile zone occurred at temperatures in excess of hornblende closure to Ar diffusion. Thus, constraining the time of motion along the ductile NSDZ is important to constraining the exhumation history.

Both of these two general problems can be addressed in the Solund-Hyllestad-Lavik area of the WGR. The Solund-Hyllestad-Lavik area is noteworthy because it 


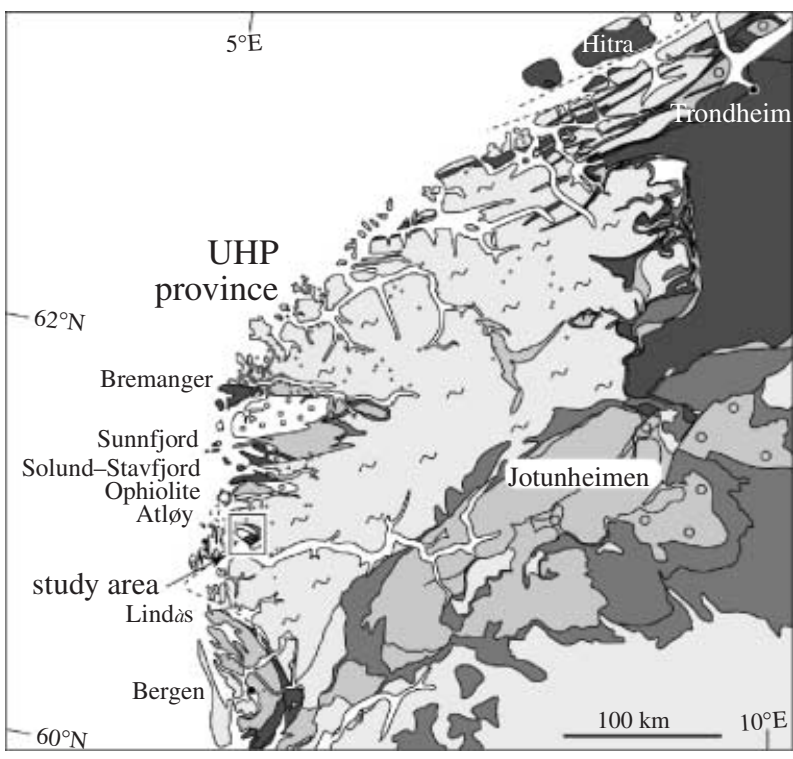

\section{TECTONOSTRATIGRAPHY}

\begin{tabular}{l}
\hline$\bullet \bullet$ \\
$\because$
\end{tabular} Devonian
(Uppermost Allochthon not
present in southern Norway)
Upper Allochthon
Ophiolitic rocks

Lower Allochthon

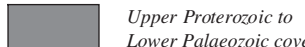

Parautochthon

\& Autochthon

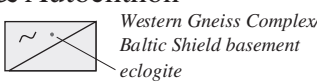

Middle Allochthon

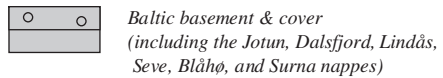

(including the Jotun, Dalsfjord, Lind

Fig. 1. Geology of southern Norway. Heavy dark lines show major extensional structures and UHP area is ruled.

contains a record of ophiolite emplacement, near-UHP metamorphism, and large-scale displacement on the NSDZ and the overlying Solund fault. The purpose of this paper is to document the emplacement and exhumation histories of high-pressure rocks in this key area.

\section{SCANDINAVIAN CALEDONIDES}

The Scandinavian Caledonides are $1700 \mathrm{~km}$ long, comparable to the length of the Himalaya. They are a type example of an orogen composed of thin $(=10 \mathrm{~km})$, far-traveled $(=300 \mathrm{~km})$, and areally extensive $\left(=50000 \mathrm{~km}^{2}\right)$ thrust sheets (Andersen, 1998). The SE-directed emplacement of these thrust sheets is conventionally explained as the result of continent-continent collision between Baltica (including Norway) and Laurentia (including Greenland). The nappes and thrust sheets are conventionally lumped into structurally distinct entities separated by regionally extensive faults: autochthon/parautochthon, Lower Allochthon, Middle Allochthon, Upper Allochthon and Uppermost Allochthon (Roberts \& Gee, 1985).

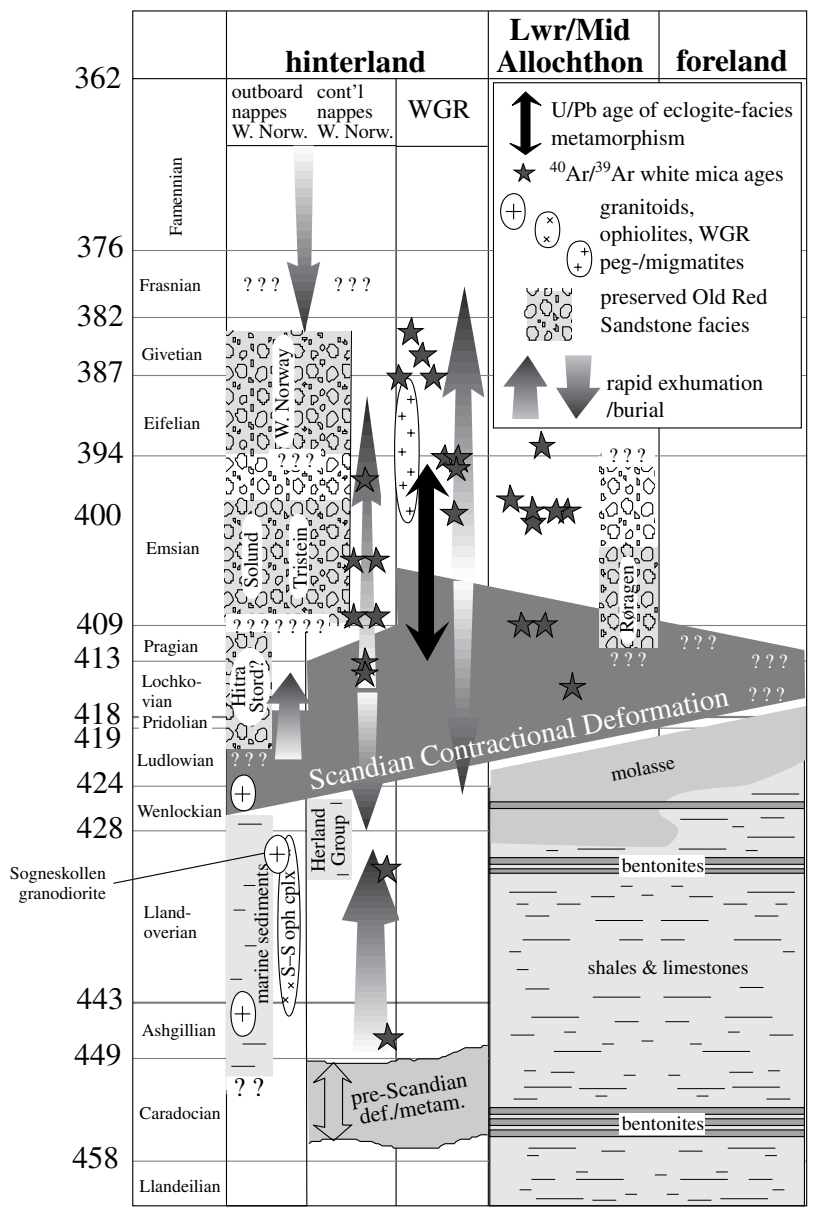

Fig. 2. Timeline of tectonic events in southern Norway. Timescale based on (Tucker et al., 1998; Tucker \& McKerrow, 1995). Beginning of Scandian deformation signaled by emplacement of Solund-Stavfjord ophiolite complex (S-S oph cplx), deposition of Herland Group, and molasse sedimentation in foreland. Switch from contraction to extension at deep levels heralded by white-mica ages in the Western Gneiss Region (WGR).

\section{Geological Units}

The autochthon/parautochthon is the west-facing passive margin of Baltica, which consists of Archean to Proterozoic crystalline basement overlain by Upper Proterozoic rift sediments, Cambrian to Wenlockian shelf sediments, and Ludlovian-Pridolian molasse (Fig. 2) (Bockelie \& Nystuen, 1985). West of the autochthon, and separated from it horizontally by as little as $20 \mathrm{~km}$ of overlying allochthonous units, is the Western Gneiss Complex (WGC) (Milnes et al., 1997), which contains HP and UHP eclogites; the UHP eclogites are found along the coast north of $62^{\circ} \mathrm{N}$, whereas HP eclogites crop out NE, E, $\mathrm{SE}$ and $\mathrm{S}$. The $\mathrm{S}$ and SE part of the WGC is correlated with the Baltic shield because both have basement and sedimentary cover of similar rock types and ages (Gee et al., 1994; Milnes et al., 1997; Skår, 1998), but whether the WGC is nearly autochthonous or has been displaced horizontally a significant distance is unknown.

The Lower Allochthon is composed chiefly of sedimentary rocks correlated with the sedimentary cover of the autochthon that was thrust eastward over the autochthon (Hossack et al., 1985). Orthogneisses overlain by unfossiliferous feldspathic sandstones are characteristic of the Middle Allochthon (including the Jotun, Dalsfjord, Särv and Sætra nappes) and the Seve/Blåhø/Surna 
nappes of the Upper Allochthon. Strong similarities between these sialic nappes and the Lower Allochthon and autochthon imply original contiguity (Gee \& Zachrisson, 1979), hence the sialic nappes are generally interpreted as Baltica crust or transitional continental/oceanic crust (Seve/Blåhø/Surna) that lay outboard of the WGC (Milnes et al., 1997) or as a microcontinent (Andersen \& Andresen, 1994).

The Upper Allochthon includes predominantly intraoceanic arc and marginal basin assemblages (Stephens \& Gee, 1985). Its oldest plutonic and volcanic rocks have zircon ages in the range of 497$472 \mathrm{Ma}$. Intercalated and overlying sediments have late Arenigianearly Llanvirnian (c. $470 \mathrm{Ma}$ ) fossils of Baltica, Laurentian, or mixed Laurentian-Baltica affinity, implying local geographic separation from Baltica (Pedersen et al., 1992; Sturt et al., 1991). Sr isotopes in stitching plutons reveal that the Karmøy and Lykling ophiolites were emplaced onto continental crust by $474 \mathrm{Ma}$, and the Vågåmo Ophiolite was faulted onto the arenaceous Heidal Series before deposition of the overlapping late Arenigian-early Llanvirnian Otta Conglomerate (Sturt et al., 1991). The Heidal Series rests depositionally on crystalline Baltica basement, mandating ophiolite emplacement onto the Baltica margin (Sturt et al., 1991).

These Late Cambrian-Early Ordovician ophiolites are intruded/overlain by Ordovician to Silurian arc plutonic and volcanic rocks, Ashgillian (449-443 Ma) limestones, Llandoverian (443$428 \mathrm{Ma}$ ) black shales and turbidites and volcanic rocks of unknown age (cf. Andersen \& Andresen, 1994). The Ashgillian-Llandoverian sedimentary rocks are similar to the Lower Allochthon, implying proximity to Baltica (Stephens \& Gee, 1985). The Sulitjelma $(437 \pm 2 \mathrm{Ma})$ and Solund-Stavfjord $(443 \pm 3 \mathrm{Ma})$ ophiolites may have formed exclusively at this time. Many of these oceanic rocks, plus the Uppermost Allochthon (ascribed to Laurentia) and the westernmost edge of the WGC, are intruded by a suite of gabbroic through granitic plutons and dykes ranging in age from 443 to $432 \mathrm{Ma}$. Two features suggest that this intrusive event predated emplacement of the oceanic nappes onto the Baltica margin: (i) intrusions of this age are absent within all units structurally below the oceanic nappes and above the parautochthon; and (ii) plutons piercing the Uppermost Allochthon have $\mathrm{Sr}$ initial ratios $=0.706$, implying crustal contamination, whereas plutons piercing the oceanic nappes have $\mathrm{Sr}$ initial ratios $<0.706$, implying that they did not interact with the continental rocks that currently underlie the oceanic nappes (references listed below).

\section{Allochthon emplacement and extension history}

Initial emplacement of the allochthons onto the Baltica craton can be constrained as Wenlockian (428-423 Ma) by several criteria (Fig. 2) (Greiling et al., 1998). (i) On the island of Atløy, the Wenlockian Herland Group was deposited during emplacement of the SolundStavfjord ophiolite on Middle Allochthon basement and cover (Dalsfjord Suite and Høyvik Group) (Andersen et al., 1998; Andersen \& Jamtveit, 1990; Andersen et al., 1990). (ii) As noted above, 443-432 Ma plutons have $\mathrm{Sr}$ isotopic ratios and a spatial distribution that suggest that their intrusion predates allochthon emplacement. (iii) The youngest sedimentary rocks in the Lower Allochthon are Wenlockian (Bassett, 1985), requiring that the faults bounding the Lower Allochthon be no older than Wenlockian. (iv) The youngest sedimentary rocks in the Upper Allochthon are upper Llandoverian (c. $430 \mathrm{Ma}$ ), and these are overlain by a thick turbiditic succession that may stretch into the Wenlockian (Bassett, 1985), requiring that the faults bounding the Upper Allochthon be no older than upper Llandoverian. (v) The absence of post-Wenlockian strata throughout the allochthons, with the exception of the extension-related Late Silurian (?) to Middle Devonian continental basins, implies ongoing tectonism. (vi) The transition from marine carbonate platform to continental fluvial molasse sedimentation in the foreland took place in the latest Wenlockian (Fig. 2). (vii) Similarities in the 420-430 Ma palaeomagnetic poles for Baltica, Scotland and North America imply that Baltica collided, probably obliquely, with Laurentia at this time (Torsvik, 1998). (viii) The southward transgression of flysch from Laurentia (Scotland) onto Avalonia (S Ireland) also indicates a late Llandoverian-early Wenlockian continental collision (Soper et al., 1992).

Toward the end of the Scandian orogeny (Fig. 2), Devonian sedimentary rocks were deposited unconformably on the Lower, Middle and Upper Allochthons (Norton et al., 1987; Séguret et al., 1989; Séranne \& Séguret, 1987). Fossils within these basins are Ludlovian(?)-Pridolian through Emsian-Eifelian (Siedlecka, 1975) or possibly upper Llandoverian-lower Wenlockian on Hitra, Lower Devonian in the Røragen basin, and Ludlovian through Pridolian(?) in the Oslo graben (see summaries in Bockelie \& Nystuen, 1985; Steel et al., 1985). The sedimentation in and structure of the western Norway basins were controlled by an early system of normal and strike-slip faults (Andersen, 1998; Cuthbert, 1991; Osmundsen \& Andersen, 2001; Osmundsen et al., 1998).

Following their emplacement onto the Baltica continental margin, the Caledonide thrust sheets were reworked by a major extensional event that resulted most significantly in collapse of the thrust sheets and exhumation of eclogites in the WGC. The bestknown extensional structure is the Nordfjord-Sogn detachment zone (NSDZ). The NSDZ carried the Middle and Upper Allochthons and overlying Devonian sedimentary rocks in the hanging wall down to the west over eclogite-bearing gneisses of the WGC in the footwall (Norton, 1987). The horizontal displacement on the NSDZ is at least $70 \mathrm{~km}$, but even allowing for a considerable vertical shortening component in the footwall (Andersen et al., 1994; Dewey et al., 1993), this is probably insufficient to account for the juxtaposition of $c$. 3 GPa eclogites with Devonian sedimentary rocks in the hanging wall, indicating earlier or coeval contributions from another exhumation process.

\section{SOLUND-HYLLESTAD-LAVIK AREA GEOLOGY}

The significance of the Solund-Hyllestad-Lavik area (Fig. 3) stems from its exposure of (i) one of the rare syn-kinematic plutons in the Norwegian Caledonides, the Sogneskollen granodiorite (Skjerlie et al., 2000); (ii) a nearly complete stack of the Caledonian nappes and overlying sediments; and (iii) an excellent structural section from the WGC up through the Upper Allochthon, the Solund fault, and into the Solund Devonian Basin.

The Western Gneiss Complex (WGC) is the structurally lowest unit in the area. It is chiefly a granitic to gabbroic orthogneiss with sparse lenses of eclogite. Except for the eclogite blocks, the WGC in the Solund-Hyllestad-Lavik area is dominantly amphibolite facies and has a weak retrograde greenschist facies overprint. Structurally above the WGC is the Hyllestad Complex, named and subdivided by Tillung (1999) into the Aksevatn psammite, Kleive mafic schist, Gåsetjørn pelite, Sæsol semipelite and Nygård amphibolite. The lowest of these units, the Aksevatn psammite, is a quartzose metasandstone. The WGC contains structurally interleaved layers of similar rocks with local pebbly layers, suggesting that this unit may have been deposited on the WGC, analogous to basal conglomerates elsewhere in the WGR (Tillung, 1999). The Kleive mafic schist is characterized by hornblende + biotite + garnet + plagioclase assemblages, the Gåsetjørn pelite contains local highly aluminous horizons with kyanite + staurolite + garnet + chloritoid, and the Sæsol semipelite includes marble to calc-silicate layers. The Nygård unit comprises epidote + biotite amphibolites and minor felsic gneisses and may represent a highly attenuated sheet of allochthonous basement (Tillung, 1999).

The overlying Hyllestad Complex is $c .1 \mathrm{~km}$ thick and has been correlated with the Lower Allochthon (Chauvet \& Dallmeyer, 1992; Swensson \& Anderson, 1991) or the Høyvik Group of the Middle Allochthon on Atløy (Tillung, 1999); all three units contain similar highly aluminous pelites. If correlative with the Lower Allochthon, which elsewhere contains sedimentary rocks as young as Wenlockian, this places an older limit on the metamorphic age of the Hyllestad Complex. If correlative with the Høyvik Group, which (i) lies depositionally on top of the Jotun-like Dalsfjord Suite (Brekke \& Solberg, 1987) (ii) is depositionally overlain by the Wenlockian Herland Group (Andersen et al., 1990; Brekke \& 


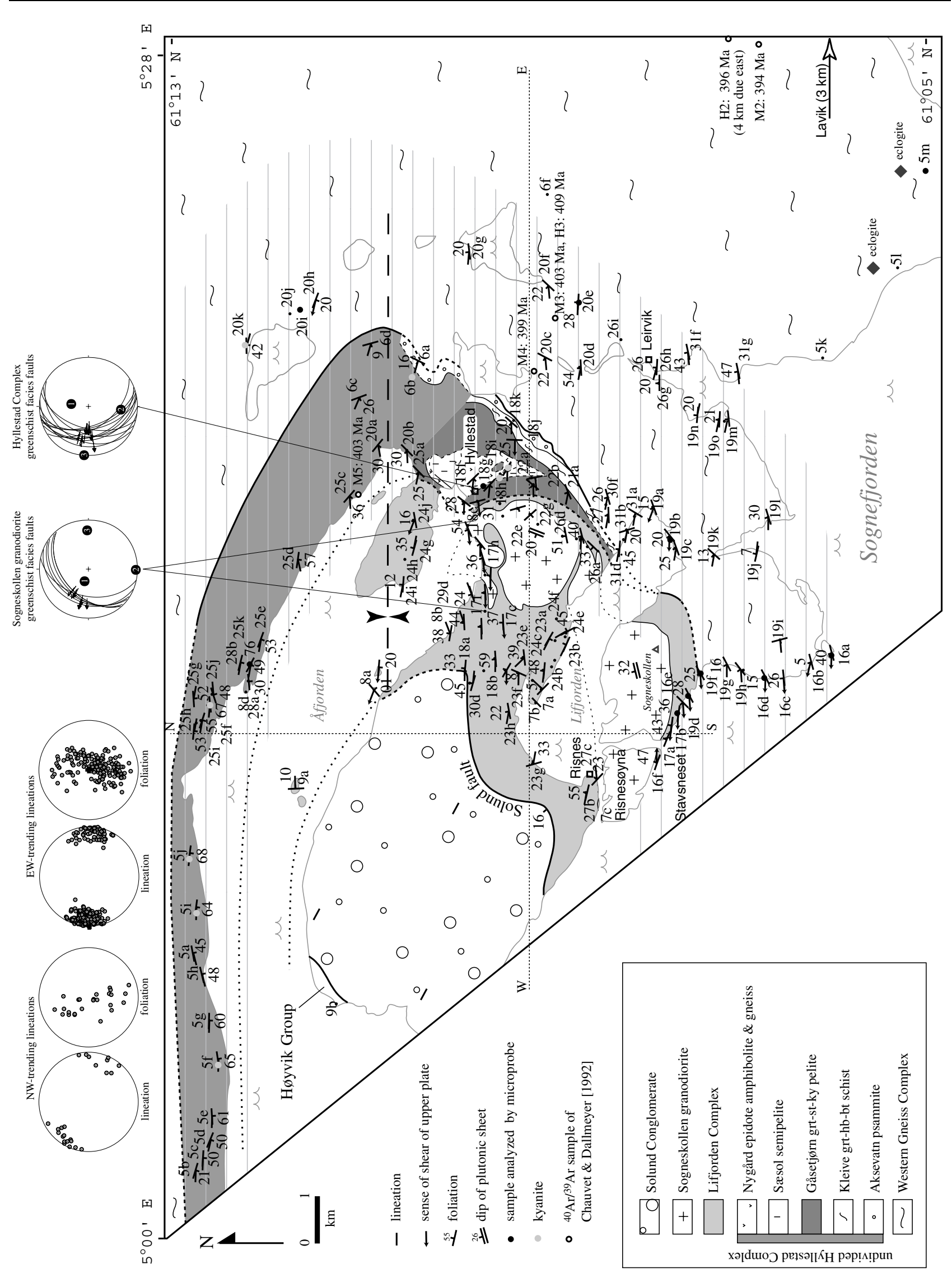



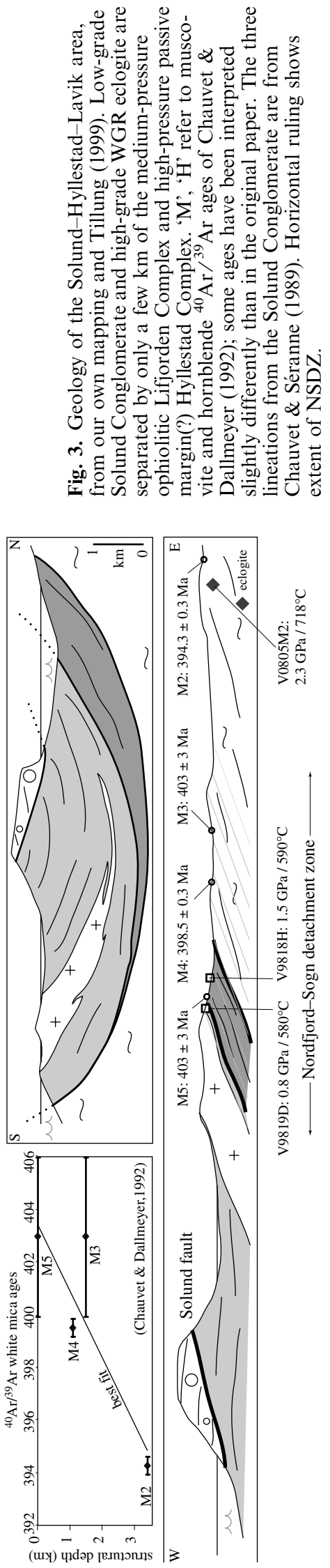

Solberg, 1987), and (iii) contains muscovite with c. $447 \mathrm{Ma}{ }^{40} \mathrm{Ar} /$ ${ }^{39} \mathrm{Ar}$ ages (Andersen et al., 1998), the Hyllestad Complex is older than $447 \mathrm{Ma}$

Structurally overlying the Hyllestad Complex is the Lifjorden Complex (Tillung, 1999), which consists of c. $3 \mathrm{~km}$ structural thickness (Fig. 3) of mostly metagraywacke, greenschist and greenstone, with minor serpentinite, metagabbro, chert, quartzose sandstones, marble and volcanogenic conglomerates. The greenstones, serpentinites and metagabbros occur chiefly toward the bottom of the section, whereas the top of the section is dominantly clastic (Tillung, 1999). The volcanogenic conglomerates, which appear in the middle of the section, include pebbles to cobbles of chiefly greenstone, plus sandstone, metagabbro, granodiorite and quartzose rock in a volcanogenic matrix (Tillung, 1999). The rock types and deformation of the Lifjorden Complex are similar to, and probably correlative with, the Staveneset Group (Furnes et al., 1990) metagraywacke and metavolcanic rocks that overlie the 443-Ma SolundStavfjord Ophiolite just west of the study area (Fig. 1, Skjerlie et al., 2000).

The youngest unit in the area is the Devonian conglomerates and minor sandstones of the Solund Basin (Nilsen, 1968), which crops out in the Solund, Bulandet and Værlandet areas (Steel et al., 1985). The unit is $>6 \mathrm{~km}$ thick and contains probable Early Devonian fossils (Steel et al., 1985), a broad spectrum of proximally derived graywacke, quartzite, greenstone and gabbro cobbles, and giant landslide deposits. The landslides contain an Early Silurian rhyolite with a $\mathrm{U} / \mathrm{Pb}$ zircon age of $439 \pm 1 \mathrm{Ma}$ (Hartz et al., in press). Sedimentary structures indicate north-westward flow of braided streams on alluvial fans built against a NW-dipping fault scarp (Nilsen, 1968). While most of the Devonian basin in the study area are underlain by the Solund fault, it rests depositionally on the Solund-Stavfjord Ophiolite, and on the Høyvik Group at the west end of the study area (Fig. 3).

\section{SOGNESKOLLEN GRANODIORITE}

The Sogneskollen granodiorite is a medium- to fine-grained leucocratic granodiorite to quartz monzonite with $<5 \mathrm{vol} \%$ biotite and epidote (Skjerlie et al., 2000; Tillung, 1999). The epidote occurs in clusters of crystals commonly associated with biotite and is interpreted as magmatic (Tillung, 1999).

The granodiorite forms a sheetlike body intruding the Lifjorden Complex that is $>300 \mathrm{~m}$ thick and dips $c .20^{\circ}$ west. Skjerlie et al. (2000) interpreted the high $\mathrm{Ba}, \mathrm{Sr}$, and $\mathrm{Na} / \mathrm{K}$, and low $\mathrm{Y}$, $\varepsilon_{\mathrm{Nd}}{ }^{87} \mathrm{Sr} /{ }^{86} \mathrm{Sr}$ and HREE concentrations to indicate formation of the Sogneskollen granodiorite by melting of hydrous sediments outside the stability field of calcic plagioclase and within the stability field of garnet. They specifically proposed that the Sogneskollen granodiorite formed from melting of graywackes like the Lifjorden Complex during thrusting beneath the Solund-Stavfjord Ophiolite. Granite veins and dykes with similar compositions are common in the upper parts of the obduction melange thrust on top of the Herland Group in the Sunnfjord area (Osmundsen \& Andersen, 1994; Skjerlie et al., 2000). Similar high-Sr and $\mathrm{Ba}$, biotite-epidote granites with $\mathrm{Rb} / \mathrm{Sr}$ whole-rock ages of $430 \pm 10$ and $430 \pm 6 \mathrm{Ma}$ and $\mathrm{Sr}$ initial ratios of $0.7056-0.7066$ intrude ophiolites and metagreywackes of the Upper Allochthon south of Bergen (Andersen \& Jansen, 1987; Fossen \& Austrheim, 1988)

In general the pluton is strongly affected by the extensional fabrics described below, but locally, the base of the pluton has been sheltered from the deformation and details of its original intrusive relationships may be discerned. The basal contact is a $c .10 \mathrm{~m}$ thick swarm of aplite and plagioclase-porphyry dykes ('grey dykes' of Skjerlie et al., 2000) (Fig. 4). Both types of dyke are mutually intrusive, although the aplites appear to record a slightly more complex deformation history, implying that they began intruding first. The aplite dykes are $<1 \mathrm{~m}$ in width and have a mutually intrusive relationship with the pluton. The plagioclase-porphyry dykes cut the pluton; they consist of plagioclase in a fine-grained matrix of quartz, epidote, feldspar and biotite, and are slightly elevated in $\mathrm{Fe}+\mathrm{Ti}$ relative to the pluton (Tillung, 1999). 


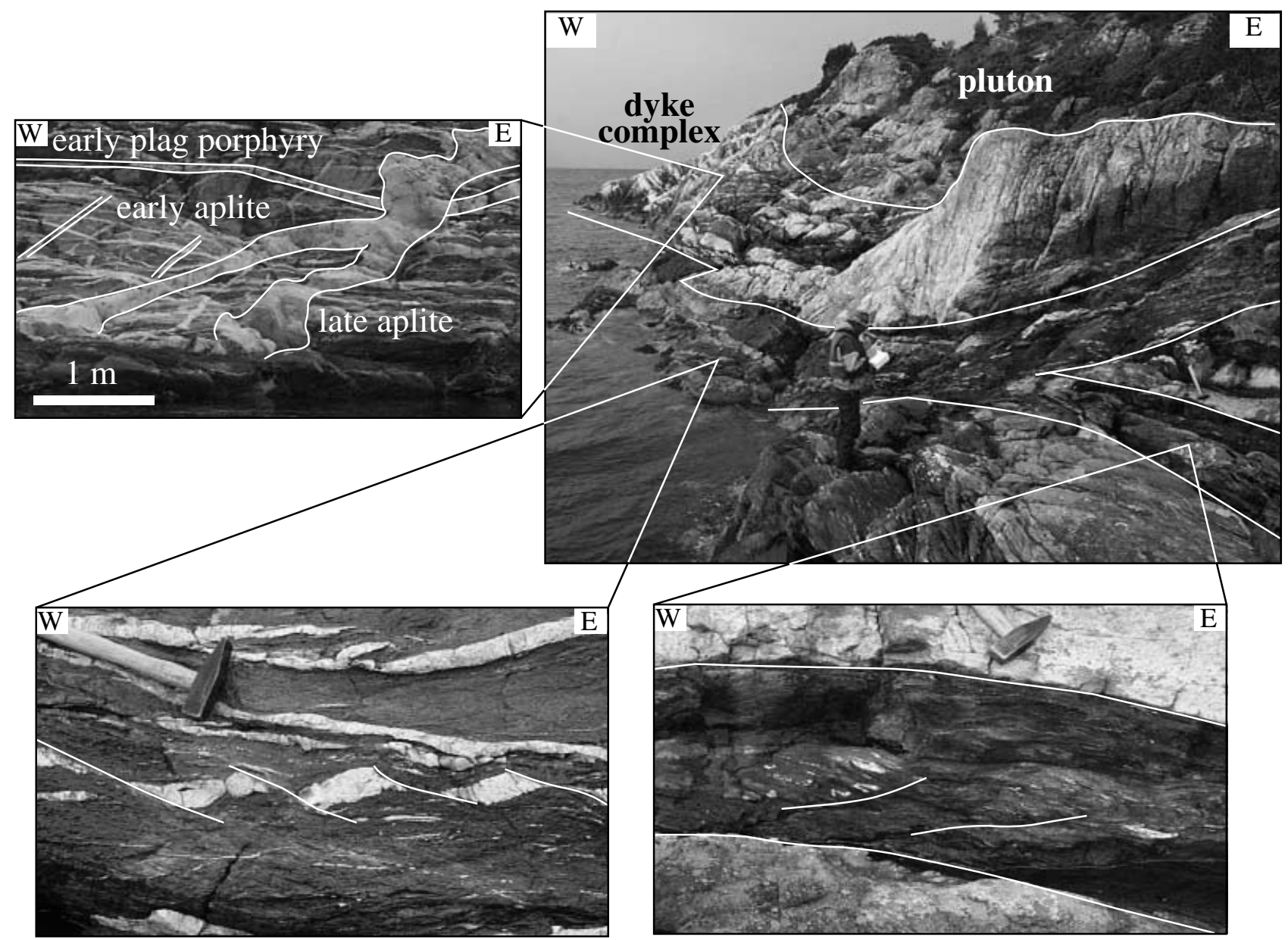

Fig. 4. Ductile shear zone at the base of the Sogneskollen granodiorite shows coaxial to weak top-E fabrics in wallrock graywacke and early aplite dykes (lower left), and top-W simple shear in younger plagioclase porphyries (lower right).

\section{METAMORPHIC PETROLOGY}

Metamorphic grade increases downsection in the Solund-Hyllestad-Lavik area. The Solund Conglomerate reached prehnite-pumpellyite facies (Norton, 1987) during a metamorphic episode that must post-date the Early Devonian depositional age of the sediments. The Lifjorden Complex above the Sogneskollen granodiorite is generally of greenschist facies, with quartz + plagioclase + muscovite + biotite stable in metasedimentary rocks and the same minerals plus epidote and chlorite in volcanogenic rocks. Garnet was found at two localities above the Sogneskollen granodiorite, in metasedimentary rock at V0807a and in metamafic rock at V0807c.

The portion of the Lifjorden Complex beneath the Sogneskollen granodiorite, the bulk of the Hyllestad Complex and the non-eclogitic rocks of the WGC, contain amphibolite facies assemblages of biotite + muscovite + plagioclase + quartz \pm garnet in felsic rocks and biotite + hornblende + plagioclase + quartz \pm garnet in mafic varieties (mineral compositions in Table S1). Most of the garnet-bearing rocks are in the Hyllestad Complex. All the garnet show bell-shaped $\mathrm{Mn}$ profiles, implying that temperatures remained too low for volume diffusion $\left(<600{ }^{\circ} \mathrm{C}\right.$, Florence \& Spear, 1991). All the aluminous samples contain garnet with core-to-rim increases in $\mathrm{Mg \#}$ and decreases in $\mathrm{Ca}$. The increase in $\mathrm{Mg} \#$ implies growth during increasing temperature for these mineral assemblages, but the decrease in $\mathrm{Ca}$ is more difficult to assess because of the consumption of plagioclase and the growth of paragonite. Using THERMOCALC, we assessed pressures and temperatures for garnet-bearing samples, and recalculated pressures and temperatures for the 'micaschist' and 'gneiss' samples of Chauvet et al. (1992) (Table 1). Metamorphic conditions for the felsic rocks, assessed chiefly with garnet-biotite $\mathrm{Fe}-\mathrm{Mg}$ thermometry and garnet-biotite-muscovite-plagioclase barometry, fall mostly in the range $500-600{ }^{\circ} \mathrm{C}, 0.7-0.9 \mathrm{GPa}$, implying metamorphism at depths of $c .30 \mathrm{~km}$. The two mafic rocks, evaluated with garnet-hornblende $\mathrm{Fe}-\mathrm{Mg}$ thermometry and garnet-hornblende-plagioclasequartz barometry, fall in the same range. 
Higher peak pressures, indicating metamorphism at depths of $c .50 \mathrm{~km}$, are recorded by highly aluminous and ferric rocks in the Gåsetjørn unit that contain subassemblages of garnet + staurolite + kyanite + chloritoid + paragonite + muscovite + quartz without biotite or talc (Chauvet et al., 1992). Textural relationships indicate that garnet, staurolite, chloritoid and kyanite constitute the highest-pressure equilibrium assemblage. This aluminous paragenesis defines a reaction $\left(575-600{ }^{\circ} \mathrm{C}\right.$ and $\left.1.4-1.6 \mathrm{GPa}\right)$ in the KFMASH system where staurolite + chloritoid change to kyanite + garnet with increasing pressure or temperature (program GIBBS v. 2/01, Spear \& Menard, 1989) (Fig. 4; Table 1). Two Hyllestad Complex samples (V9818I \& V9825f) contain kyanite + staurolite + garnet, which defines a narrow $P-T$ region from $575^{\circ} \mathrm{C}, 1.6 \mathrm{GPa}$ to $670{ }^{\circ} \mathrm{C}$, $0.7 \mathrm{GPa}$; with THERMOCALC, $P-T$ conditions were calculated near the high- $P$ end of this divariant field for sample V9818I.

Textures and mineral zoning reveal that the $P-T$ path leading to the peak recorded conditions involved heating. (i) Aluminous sample V9819H2 contains chloritoid inclusions in garnet, indicating that chloritoid-consuming reactions were active during the prograde path. (ii) Sample V9820I has the Fe-rich assemblage garnet + staurolite + biotite; the staurolite is small and rare, and garnet contains chloritoid and chlorite inclusions, suggesting progression from the garnet-chloritoid-chlorite field to higher temperatures, across the chloritoid $=$ garnet + biotite + chlorite and garnet + chlorite $=$ staurolite + biotite reactions. Using the program GIBBS (Spear \& Menard, 1989), inverse modelling of zoning in $\mathrm{Fe}-\mathrm{Mg}$ phases, and forward $P-T$ path modelling to replicate the zoning observed in garnet, we calculate that the prograde path for sample V9820I involved a pressure increase of $450 \mathrm{MPa}$ and a temperature increase of $80{ }^{\circ} \mathrm{C}$. (iii) All noneclogite garnet exhibit core-to-rim increases in $\mathrm{Mg \#}$, and plagioclase in garnet-epidote bearing rocks shows core-to-rim increases in $\mathrm{Ca}$.

Retrograde metamorphism of the aluminous rocks involved nearly isothermal decompression. Two distinctive mineral assemblages developed in the

Table 1. Thermobarometry results.

\begin{tabular}{|c|c|c|c|c|c|c|}
\hline Sample & Minerals & Thermometer & Barometer & $\mathrm{T}\left({ }^{\circ} \mathrm{C}\right)$ & $\mathrm{P}$ (kbar) & cor \\
\hline V9816A1 & $\begin{array}{l}\text { Grt Ms Bt Pl } \\
\text { Qtz Chl Rt }\end{array}$ & KFMASH grid & Grt Bt Ms Pl & $540-610$ & $9.4 \pm 1.0$ & $\mathrm{n} / \mathrm{a}$ \\
\hline V9816D2 & $\begin{array}{l}\text { Grt Hbl Bt Ms Pl } \\
\text { Qtz Rt Ep }\end{array}$ & Grt-Bt & Grt Bt Ms Pl & $560 \pm 50$ & $7.5 \pm 0.8$ & 0.917 \\
\hline V9818G & $\begin{array}{l}\text { Grt Hbl Ms Pl } \\
\text { Qtz Chl Rt Ep }\end{array}$ & Grt-Hbl & Grt Hbl Pl Qtz & $523 \pm 39$ & $7.4 \pm 0.9$ & 0.651 \\
\hline $\mathrm{V} 9818 \mathrm{H}$ & $\begin{array}{l}\text { Ky St Cld Grt Ms } \\
\text { Qtz Rt Sil }\end{array}$ & KFMASH grid & & $575-600$ & $14-16$ & $\mathrm{n} / \mathrm{a}$ \\
\hline \multirow[t]{3}{*}{ V9818I1 } & Ky St Grt Ms Pg & $\begin{array}{l}\text { Ky Grt St Ms } \\
\text { Qtz intersection }\end{array}$ & & $616 \pm 201$ & $18.4 \pm 6.6$ & 0.959 \\
\hline & Qtz Chl Rt Sil & KFMASH grid & & $575-670$ & $7.4-16$ & $\mathrm{n} / \mathrm{a}$ \\
\hline & & KFMASH grid & $\begin{array}{l}\text { Ky Grt St Ms } \\
\text { Qtz reaction }\end{array}$ & $570-585$ & $15-16$ & $\mathrm{n} / \mathrm{a}$ \\
\hline \multirow[t]{2}{*}{ V9818I9B } & $\begin{array}{l}\text { Ky St Cld Grt Ms Pg } \\
\text { Rt Sil }\end{array}$ & $\begin{array}{l}\text { Ky St Grt Ms } \\
\text { Qtz intersection }\end{array}$ & & $595 \pm 175$ & $14.5 \pm 5.0$ & 0.930 \\
\hline & & KFMASH grid & & $575-600$ & 14-16 & \\
\hline \multirow[t]{2}{*}{ V9819D } & Grt Hbl Ms Bt Pl & Grt-Bt & Grt Bt Ms Pl & $580 \pm 48$ & $8.3 \pm 0.8$ & 0.845 \\
\hline & Qtz Chl Rt Ep Ilm & Grt-Hbl & Grt Hbl Pl Qtz & $577 \pm 38$ & $5.0 \pm 1.2$ & 0.405 \\
\hline \multirow[t]{2}{*}{ V9819E } & Grt Hbl Ms Grt Pl & Grt-Bt & Grt Bt Ms Pl & $520 \pm 72$ & $7.2 \pm 0.8$ & 0.875 \\
\hline & Qtz Chl Rt Ep & Grt-Hbl & Grt Hbl Pl Qtz & $521 \pm 36$ & $5.4 \pm 0.8$ & 0.583 \\
\hline \multirow[t]{2}{*}{ V9819F } & Grt $\mathrm{Hbl} \mathrm{Ms} \mathrm{Bt} \mathrm{Pl}$ & Grt-Bt & Grt Bt Ms Pl & $543 \pm 46$ & $7.4 \pm 0.7$ & 0.850 \\
\hline & Qtz Chl Rt Ep Ilm & Grt-Hbl & Grt $\mathrm{Hbl} \mathrm{Pl} \mathrm{Qtz}$ & $513 \pm 34$ & $4.6 \pm 0.9$ & 0.430 \\
\hline V9820E & $\begin{array}{l}\text { Grt } \mathrm{Hbl} \mathrm{Bt} \mathrm{Pl} \\
\text { Qtz Rt Ep }\end{array}$ & Grt-Hbl & Grt Hbl Pl Qtz & $552 \pm 38$ & $8.7 \pm 0.8$ & 0.755 \\
\hline V9820I & $\begin{array}{l}\text { Grt St Ms Bt Pl } \\
\text { Qtz Ep }\end{array}$ & KFMASH grid & Grt Bt Ms Pl & $600-630$ & $10.3 \pm 1.1$ & $\mathrm{n} / \mathrm{a}$ \\
\hline V9820K & $\begin{array}{l}\text { Grt Hbl Bt Pl } \\
\text { Qtz Chl Rt Ilm }\end{array}$ & Grt $-\mathrm{Hbl}$ & Grt Hbl Pl Qtz & $585 \pm 39$ & $7.7 \pm 0.7$ & 0.651 \\
\hline \multirow[t]{2}{*}{ V9825F } & Ky St Grt Ms Bt Pl & Ky St Grt Bt Ms & Qtz intersection & $614 \pm 56$ & $11.4 \pm 2.2$ & -0.41 \\
\hline & Qtz Chl Rt & KFMASH grid & Grt ASt Pl & $620 \pm 10$ & $11.8 \pm 1.1$ & $\mathrm{n} / \mathrm{a}$ \\
\hline V0805M 1 & Grt Om Pg Ms & Grt Om Pg & Grt Om Pg Ms & $687 \pm 77$ & $22.1 \pm 2.2$ & 0.515 \\
\hline V0805M 2 & Grt Om Pg Ms & Grt Om Pg & Grt Om Pg Ms & $718 \pm 83$ & $24.7 \pm 2.4$ & 0.670 \\
\hline EC§ & Grt Om Pg & Grt Om Pg Ms & & $654 \pm 72$ & $23.0 \pm 1.8$ & 0.475 \\
\hline MS§ & & Grt-Bt & Grt Bt Ms Pl & $516 \pm 44$ & $6.9 \pm 0.7$ & 0.881 \\
\hline GNß & & Grt-Bt & Grt Bt Ms Pl & $607 \pm 59$ & $9.1 \pm 1.0$ & 0.953 \\
\hline
\end{tabular}

Note: 'KFMASH grid' refers to pelite phase diagram produced with Gibbs (Spear \& Menard, 1989) from Powell \& Holland 1998 database; 'reaction' and 'intersection' refer to THERMOCALC v3.1 with May, 2001 database

(Powell \& Holland, 1988). Mineral formulae and activities were calculated with the program 'A-X', by T.J.B. Holland and R. Powell; A-X calculates $\mathrm{Fe}^{3+}$ in clinopyroxene using charge balance considerations, which Carswell et al. (2000) demonstrated is a good approximation to $\mathrm{Fe}^{3+}$ measured by Mössbauer spectrometry. Uncertainties are $\pm 1 \sigma$; 'cor' is correlation coefficient from THERMOCALC. §: calculations based on mineral compositions reported by Chauvet et al. (1992) 


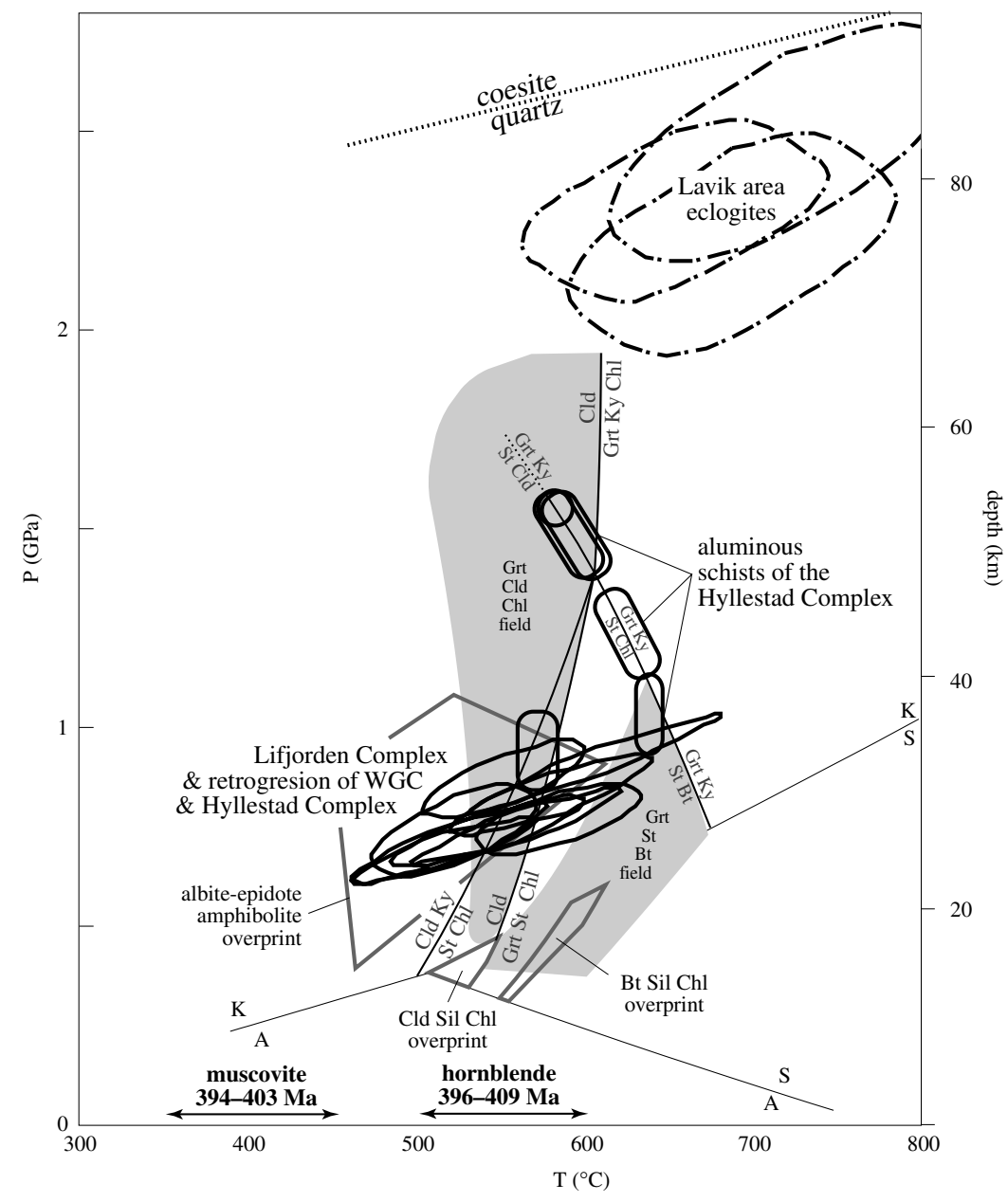

Fig. 5. Calculated pressures and temperatures for the Solund-Hyllestad-Lavik area. Eclogites in the Lavik area record peak nearUHP conditions and albite-epidote amphibolite facies overprint. Aluminous schists of the Hyllestad Complex decompressed nearly isothermally from $c .1 .5 \mathrm{GPa}$ to $0.4 \mathrm{GPa}$ at $c .600{ }^{\circ} \mathrm{C}$. Lifjorden complex was buried to depths of $c .30 \mathrm{~km}$. aluminous rocks: (i) Fe-rich chloritoid between boudinaged staurolite grains and on kyanite rims, and latestage top-W shear bands with sillimanite and chlorite (c. $500{ }^{\circ} \mathrm{C}$ and $400 \mathrm{MPa}$ ); and (ii) biotite + sillimanite + chlorite $\left(550-600{ }^{\circ} \mathrm{C}\right.$ and $\left.300-600 \mathrm{MPa}\right)$.

The Sogneskollen granodiorite predates the amphibolite facies metamorphism and associated top-W extension. Garnet atolls developed around plagioclase grains in the aplite dykes (Tillung, 1999) might have grown during at this time.

Eclogites crop out at a few localities in the Lavik area (Fig. 3). Chauvet et al. (1992) described phengite + epidote + rutile bearing eclogite variably retrogressed to amphibolite and then albite-epidoteamphibolite facies. The garnet in the examined samples are homogeneous alm $_{58}$ grs $_{21}$ prp $_{19} \mathrm{Sps}_{01}$ and contain inclusions of $\left(\mathrm{K}_{0.1} \mathrm{Na}_{0.5}\right)\left(\mathrm{Na}_{1.1} \mathrm{Ca}_{0.9}\right)\left(\mathrm{Mg}_{2.1} \mathrm{Fe}_{1.3}\right)$ $\left(\mathrm{Fe}_{0.4} \mathrm{Al}_{1.2}\right)\left(\mathrm{Al}_{1.5} \mathrm{Si}_{6.5}\right) \mathrm{O}_{22}(\mathrm{OH})_{2}$ hornblende, epidote and plagioclase, indicating prograde amphibolite facies metamorphism. Clinopyroxene is also nearly homogeneous, lacks the exsolved $\mathrm{SiO}_{2}$ rods common in eclogites farther north in the WGC and has core compositions of $\mathrm{jd}_{50-54} \mathrm{di}_{31-33} \mathrm{hed}_{11-12} \mathrm{acm}_{07-11}$;
Chauvet et al. (1992) reported much lower jadeite contents of $25-30 \mathrm{~mol} \%$ from their sample. The highest phengite content found in $\mathrm{K}$-white mica was $3.32 \mathrm{Si}$ atoms pfu, slightly less than the 3.36 reported by Chauvet et al. (1992). Following the logic outlined by Carswell et al. (2000), we used THERMOCALC to calculate $P, T_{\max }$ using the lowest $\mathrm{Fe} / \mathrm{Mg}$ garnet, highest $\mathrm{Fe} / \mathrm{Mg}$ omphacite and highest $\mathrm{Fe} / \mathrm{Mg}$ phengite compositions, and $P_{\max }, T$ using the most jadeite-rich omphacite, most siliceous phengite, and the garnet with the highest $\mathrm{a}_{\mathrm{prp}} \mathrm{a}_{\mathrm{grs}}^{2} . P-T$ were calculated based on $\mathrm{Fe}-\mathrm{Mg}$ exchange between garnet and clinopyroxene and the inverse Tschermak substitution in coexisting phengite, finding conditions of $c .700{ }^{\circ} \mathrm{C}$, $2.3 \mathrm{GPa}$ for our two eclogite samples and Chauvet et al.'s sample, regardless of whether the $T_{\max }$ or $P_{\max }$ criteria of Carswell et al. (2000) were used.

In summary, the metamorphic petrology places the following significant constraints on the evolution of the area. (1) The WGC experienced definitively higher pressures and temperatures than all overlying units, reaching $c .700{ }^{\circ} \mathrm{C}$ at $c .80 \mathrm{~km}$ depth. (2) The Hyllestad Complex experienced definitively higher pressures 
and temperatures $\left(c .600{ }^{\circ} \mathrm{C}\right.$ at $c .50 \mathrm{~km}$ depth) than the Lifjorden Complex $\left(c .550{ }^{\circ} \mathrm{C}\right.$ at $c .30 \mathrm{~km}$ depth). (3) The similarity of the prograde amphibolite facies pressures and temperatures of the Lifjorden Complex with the retrograde amphibolite facies pressures and temperatures of the Hyllestad Complex and the WGC imply that all three units shared a common late-stage history. (4) All three units reached peak conditions via a heating path, which was then followed by decompression to $c .15 \mathrm{~km}$ depth and only minor cooling of c. $50{ }^{\circ} \mathrm{C}$. (5) This metamorphism post-dates intrusion of the Sogneskollen granodiorite. (6) The pressure differences between the three major units implies considerable excision or thinning of the section. The $2.3 \mathrm{GPa}$ eclogites and the $1.5 \mathrm{GPa}$ rocks in the Hyllestad Complex are separated by only c. $2.7 \mathrm{~km}$ of structural section, implying thinning by a factor of c. 11. If this exhumation occurred along a normalsense shear zone with a dip of $40-25^{\circ}$, this corresponds to a shear strain of $17-27$. The $1.5 \mathrm{GPa}$ rocks in the Hyllestad Complex and the $0.8 \mathrm{GPa}$ rocks in the Lifjorden Complex are separated by only $c .0 .3 \mathrm{~km}$ of structural section, implying thinning by a factor of $c$. 66. If this exhumation occurred along a normalsense shear zone with a dip of $40-25^{\circ}$, this corresponds to a shear strain of $100-150$.

\section{STRUCTURE}

The large-scale structure of the study area is a $>20-\mathrm{km}$ wavelength, W-plunging synform whose axis is parallel to the regional stretching lineation. The WGC, Hyllestad Complex and Lifjorden Complex contain a gently plunging $\mathrm{E}-\mathrm{W}$ stretching lineation in most localities (Fig. 3). In the WGC and Hyllestad Complex, this lineation formed at amphibolite facies conditions, whereas the lineation in the part of the Lifjorden Complex above the Sogneskollen granodiorite formed at greenschist facies conditions. The $\mathrm{E}-\mathrm{W}$ lineation is contemporaneous with the noncoaxial top-W extension (Chauvet \& Séranne, 1989). The extensional fabric is fairly homogeneous throughout the WGC and Hyllestad Complex between Lavik and Hyllestad, but higher in the section, it is less penetrative and mafic orthogneisses along the shore south of Sogneskollen are highly phyllonitic. The portion of the Lifjorden Complex structurally beneath the Sogneskollen pluton is also strongly deformed and partly phyllonitic, except in a local strain shadow adjacent to the pluton at Risnesøyna (see above and Fig. 4). Structurally above the pluton, however, the extensional deformation is less penetrative. We interpret domains in the upper part of the Lifjorden Complex where the lineation plunges NW (Fig. 3), rather than E-W, as a younger fabric.

The most significant structural feature in the area is the ductile shear zone at the base of the Lifjorden Complex (Fig. 4). The first $10 \mathrm{~m}$ of the dyke swarm beneath the Sogneskollen granodiorite at Risnesøyna are weakly deformed, and contain important struc- tural and intrusive relationships obliterated elsewhere. Here, the intrusive relationships between aplite dykes and their envelope show that the aplites post-date early contractional folds, cleavage formation and thrust-related top-east fabrics. The country-rock greywackes between the dykes contain an S1 cleavage parallel to compositional layering, S0, that is folded into isoclinal $\mathrm{m}$-scale folds. An axial-planar cleavage, $\mathrm{S} 2$, is developed in the hinges of these folds. These folds and S1 and S2 cleavages are truncated by both the aplite and plagioclase-phyric dykes. The graywacke and aplite dykes in the low-strain zone have dominantly symmetrical structures implying dominantly coaxial deformation at the scale of the preserved low-strain zone, but locally the dykes have asymmetric boudins indicating thrust-related top-E shear. The pre to syn-granite emplacement contractional fabrics yield no evidence for HP metamorphism, supporting our interpretation of a major metamorphic pressure break below the Lifjorden complex. The plagioclase-phyric dykes truncate these fabrics and themselves locally exhibit top-W shear. At Stavsneset (Fig. 3, headland east of Risnesøyna) deformation intensifies about $50 \mathrm{~m}$ below the base of the pluton: the host graywacke develops strong top-W asymmetric fabrics, and the dykes become disrupted, asymmetrically boudinaged and transposed parallel to an intensified foliation. This zone is succeeded downward by a few metres of strongly deformed graywacke with rare boudins of the aplite and plagioclase-phyric dykes. Below this, the asymmetric top-W fabric becomes phyllonitic, strengthens abruptly and no further dykes are seen, suggesting very large shear strains and correspondingly large-scale displacement.

In aggregate, the structural and intrusive relationships reveal that the aplite dykes intruded at a late stage of the top-E thrusting, and that the top-W shear began after dyke intrusion. The plagioclase-phyric dykes exhibit variable degrees of deformation in the extensional shear bands; but we ascribe this variation to the inhomogeneous bulk strain preserved in the local strain shadow at Risnesøyna. Textbook-quality shear bands, asymmetric boudinage, $\sigma$ and $\delta$ clasts indicate pervasive top- $\mathrm{W}$ extension in all rocks exposed structurally beneath the Sogneskollen granodiorite (Fig. 4).

We measured quartz lattice preferred orientations in eight samples (Fig. 6). V9816A shows the strongest fabric, with a $c$-axis maximum parallel to $\mathrm{Y}$ and the prism planes aligned parallel to the foliation, implying prism- $<\mathrm{a}>$ slip, characteristic of amphibolite facies deformation, during coaxial deformation (Schmid \& Casey, 1986). Two other samples in the deeper part of the section are similar, whereas the remaining samples have rather weak fabrics. Only the uppermost sample, V9823F exhibits any evidence of low-temperature $<$ a $>$ slip in the basal plane.

Deformation in the Solund Basin sedimentary rocks is different than that in lower units. Pebbles 

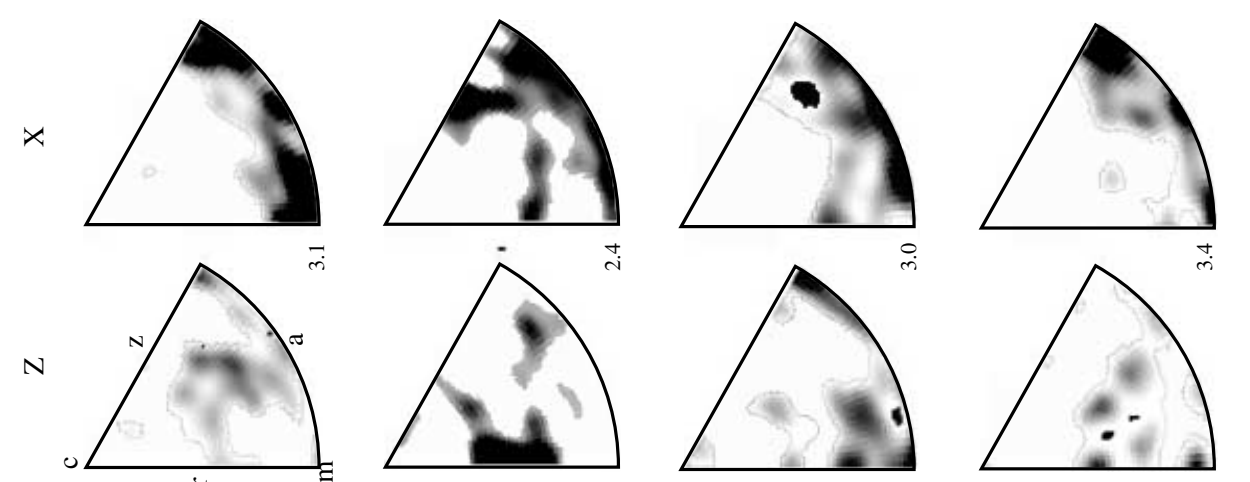

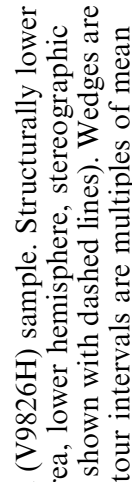
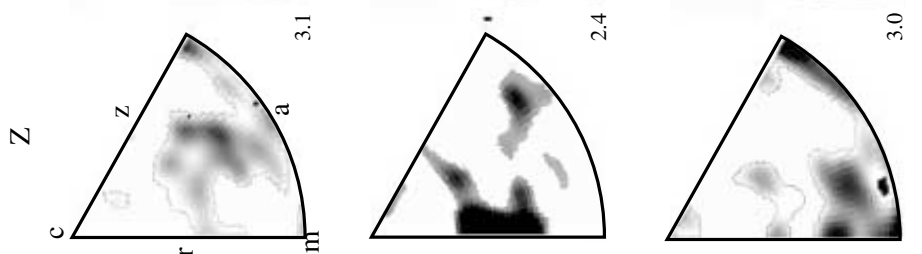

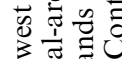
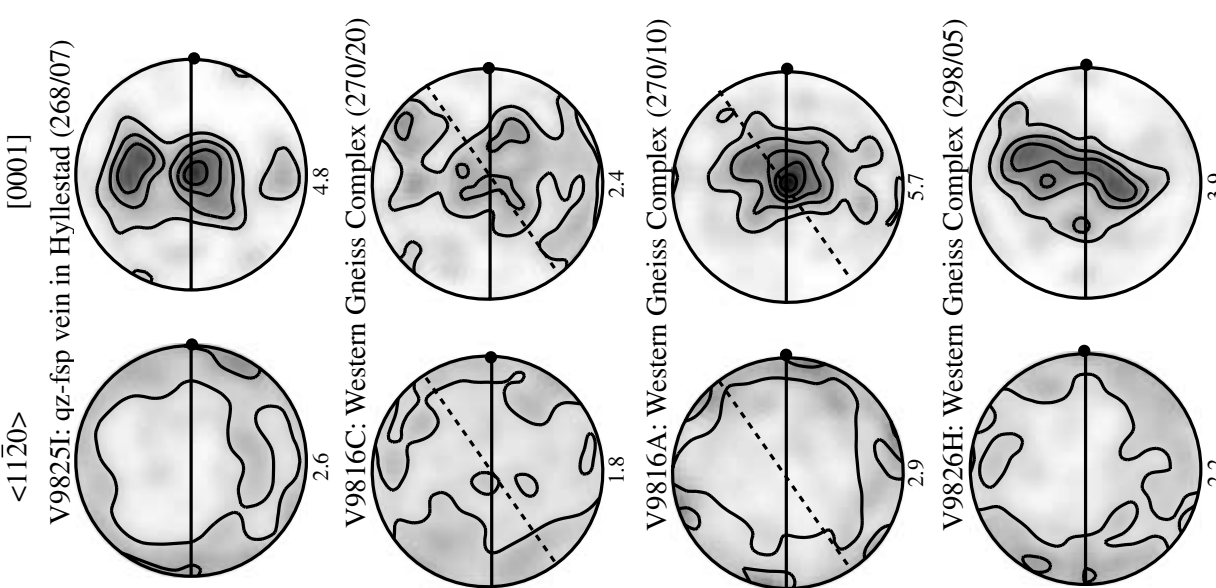

至司苛

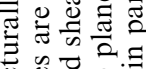

क⿺辶大

舟守宁

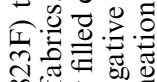
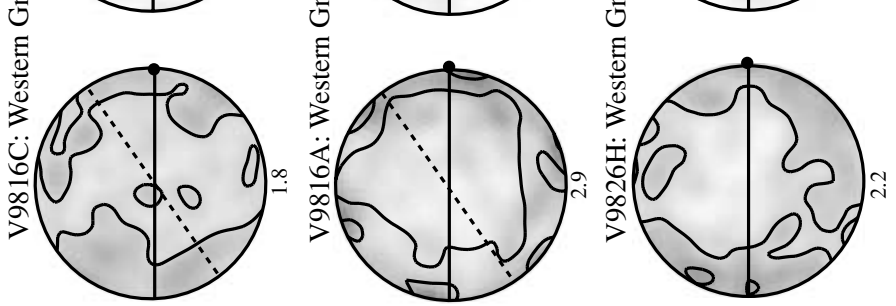

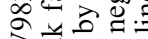

乙卷菏宁

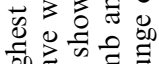

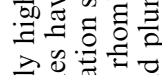

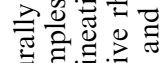

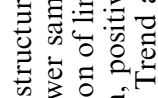
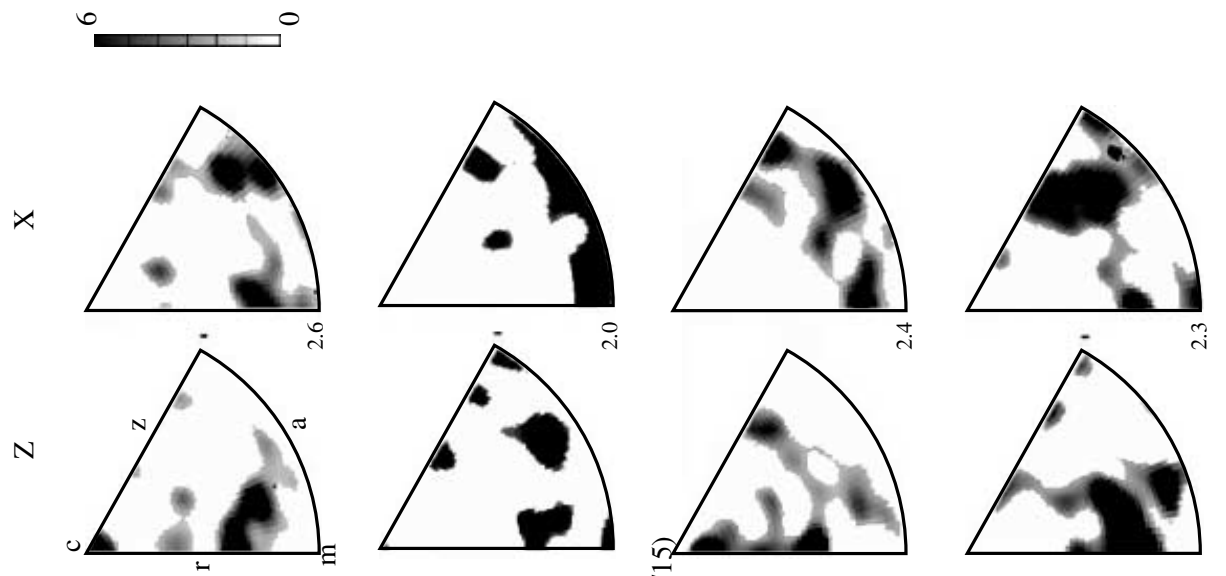

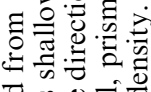

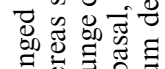

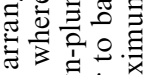

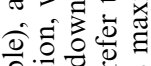

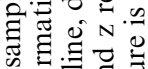

क

N
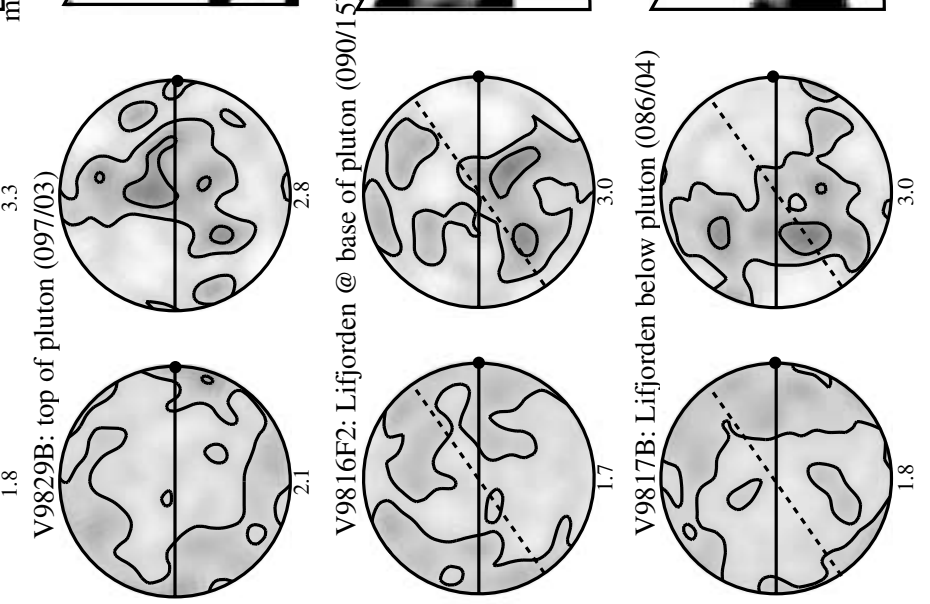

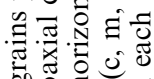

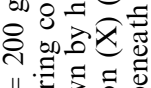

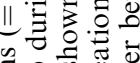

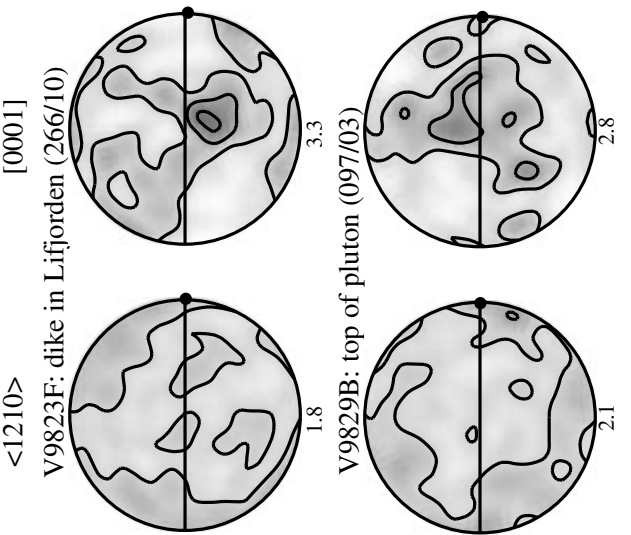

음

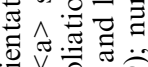

o

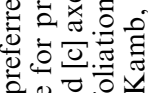

워워

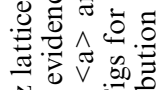

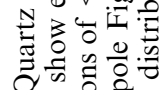

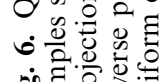

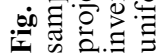


throughout the basin are oriented NW-SE (Séranne \& Séguret, 1987), and have NW-SE trending strain shadows and NE-striking tension gashes developed during metamorphism (Chauvet \& Séranne, 1989). The Solund fault, where it bounds the Solund Conglomerate, is a few-metre thick zone with pseudotachylite, ultracataclasite and ultramylonite derived mainly from the Solund Conglomerate. Outcrop/topography relations indicate a dip of $c .16^{\circ}$ toward 320 , implying that the Solund fault truncates structures within the underlying Lifjorden Complex; this is also evident in the discordant relationship between the NE-trending folds in the Solund-Bulandet-Værlandet Basin (Norton, 1987; Osmundsen \& Andersen, 2001) and the E$\mathrm{W}$ folds developed in all deeper units. The upper $7 \mathrm{~m}$ of the underlying Lifjorden Complex are mylonitized with a 302/18 stretching lineation and shear bands indicating extensional movement along the Solund fault (Norton, 1987). Less than $100 \mathrm{~m}$ beneath the Solund fault, the greenschist facies Lifjorden Complex is less deformed. It bears the folds and $S_{1}$ and $S_{2}$ foliations similar to those beneath the Sogneskollen granodiorite.

Chauvet \& Séranne's (1989) reconnaissance investigation of brittle faults within the Solund Basin also showed NW-SE extension. We measured brittle-ductile faults with quartz + chlorite + epidote mineralization at two well-exposed localities within the Sogneskollen granodiorite and Hyllestad Complex (Fig. 3). At both localities, fault-striae analysis (Ratschbacher et al., 1994), indicates roughly E-W extension after the local foliation is restored to prefolding horizontal.

Thus, the section in the Hyllestad area is marked from top to bottom by (i) NW-directed extension within the weak prehnite-pumpellyite facies Solund Conglomerate; (ii) NW-directed normal slip along the discrete Solund fault; (iii) NW-directed extension within the weakly deformed greenschist facies section of the Lifjorden Complex; (iv) W-directed extension within the Sogneskollen granodiorite; (v) the profound top-W extensional shear zone, which began at amphibolite facies conditions (sillimanite stable) and which contains the HP rocks in its footwall; and (vi) penetrative top-W extensional fabric throughout the Hyllestad Complex and extending down into the WGC at least as far as Leirvik. Features iv, v and vi comprise the NSDZ, quite different from suggestions that the NSDZ is a homogeneous $2-\mathrm{km}$ thick shear zone restricted to the Lifjorden Complex (e.g. Chauvet \& Brunel, 1988).

\section{GEOCHRONOLOGY}

Previous attempts to date zircon and titanite from the Sogneskollen granodiorite have been unsuccessful, although Skjerlie et al. (2000) reported zircon rim ionprobe spot ages of c. 450-400 Ma. Skjerlie et al. (2000) argued that the Sogneskollen granodiorite is c. $420 \mathrm{Ma}$, based on compositional similarity to a $419 \pm 9 \mathrm{Ma}$ granitic dyke from the Lindås nappe $(\mathrm{U} / \mathrm{Pb}$ zircon age, Austrheim, 1990) and the assumption that contractional structures within the Sogneskollen granodiorite developed during the Wenlockian emplacement of the Solund-Stavfjord Ophiolite.

We separated zircon from three samples for $\mathrm{U} / \mathrm{Pb}$ dating: the Sogneskollen granodiorite (V9817A3), an aplite dyke (V9817A1) and a plagioclase-phyric dyke (V9817A2). All three samples were taken from the base of the pluton and its associated dyke swarm. The zircon exhibit obvious cathodoluminescent cores and rims (Fig. 7) that proved to have high and low $\mathrm{Th} / \mathrm{U}$, respectively. As a preliminary investigation, we analyzed one fraction of zircon from each of the three samples by single-step digestion and thermal-ionization mass spectrometry (TIMS) (Fig. 8; Table S2). All three fractions are discordant. Sample V9817A3 contains both clear and strongly cloudy zircon. A small population of clear grains was used for Sensitive High Resolution Ion Microprobe (SHRIMP) work, and a fraction of the cloudy grains analysed by TIMS. This zircon has a high $\mathrm{U}$ content (c. 1100 p.p.m), and yields ${ }^{206} \mathrm{~Pb}^{*} /{ }^{238} \mathrm{U}$ and ${ }^{207} \mathrm{~Pb} * /{ }^{206} \mathrm{~Pb}^{*}$ ages of $c .373$ and c. $610 \pm 50 \mathrm{Ma}$, respectively (the large error on the ${ }^{207} \mathrm{~Pb}^{*} /{ }^{206} \mathrm{~Pb}^{*}$ age stems from a high common $\mathrm{Pb}$ content). By comparison with the other TIMS data and the SHRIMP data (discussed below), these ages suggest significant $\mathrm{Pb}$ loss plus inheritance. The $\mathrm{Pb}$ loss is unsurprising in light of the high $U$ content and cloudy appearance of the zircon. TIMS fractions V9817A1 and A2 consist of clear zircon, and are relatively low in $U$ (c. 125 and 34 p.p.m., respectively). These fractions are strongly discordant, with ${ }^{206} \mathrm{~Pb}^{*} /{ }^{238} \mathrm{U}$ and ${ }^{207} \mathrm{~Pb}^{*} /{ }^{206} \mathrm{~Pb}^{*}$ ages of 932 and $1208 \pm 1.7 \mathrm{Ma}$, respectively, for V9817A1, and 662 and $972 \pm 9 \mathrm{Ma}$, respectively, for V9817V2. For reference, these data define a lower intercept age of $437.4 \pm 9.3 \mathrm{Ma}$, but we place little confidence in this two-point intercept. For the lower intercept to have rigorous age significance, the zircon would need to have differing proportions of an inherited component of identical age (or at least identical mean age), and no post-crystallization $\mathrm{Pb}$ loss (a distinct possibility given the moderate to low $\mathrm{U}$ concentrations). In any case, the lower intercept age is in agreement with the SHRIMP results reported below and thus tends to reinforce those results.

The Sensitive High Resolution Ion Microprobe (SHRIMP) at the Stanford/USGS Microanalytical Facility was used to obtain 37 spot ages from grain cores and rims (Fig. 8). Seven spot analyses of grain cores from the aplite dyke have ages that lie along a rough mixing line from $c .0 .95$ to $c .1 .6 \mathrm{Ga}$, and $\mathrm{Th} / \mathrm{U}$ ratios of $0.2-1.3$, indicating an igneous provenance. Textural relations visible in cathodoluminesence images reveal that this range of ages is not the result of mixing of different age domains during ion-probe 

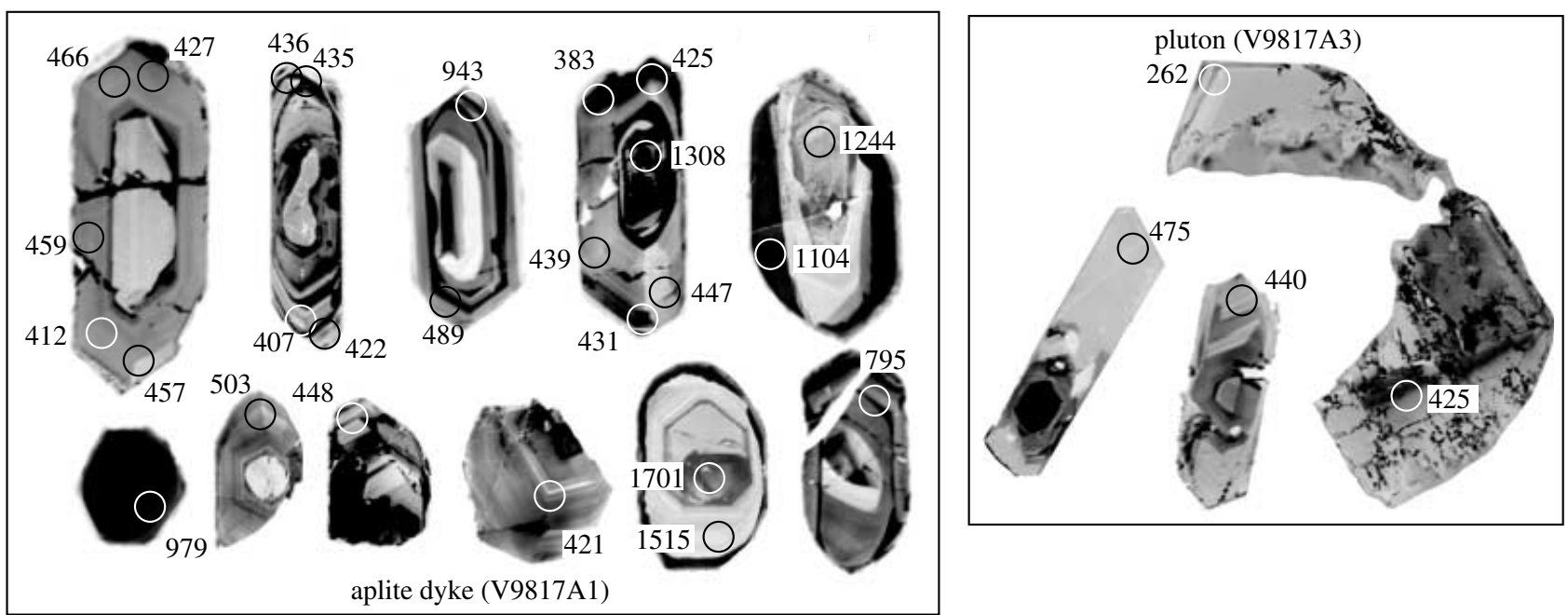

plag-porphyry dyke(V9817A2)
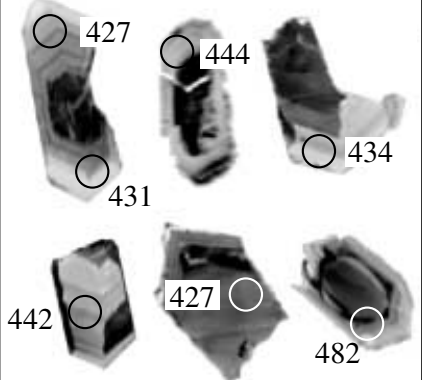

$100 \mu \mathrm{m}$

Fig. 7. Cathodoluminesence images of zircon from the Sogneskollen granodiorite and associated dykes. Cores are probably 1.6 and $0.9 \mathrm{Ga}$, rims are $c .434 \mathrm{Ma}$. Brightness of greyscale is correlated with U content. Spot ages in $\mathrm{Ma}$, corrected using measured ${ }^{207} \mathrm{~Pb}$.

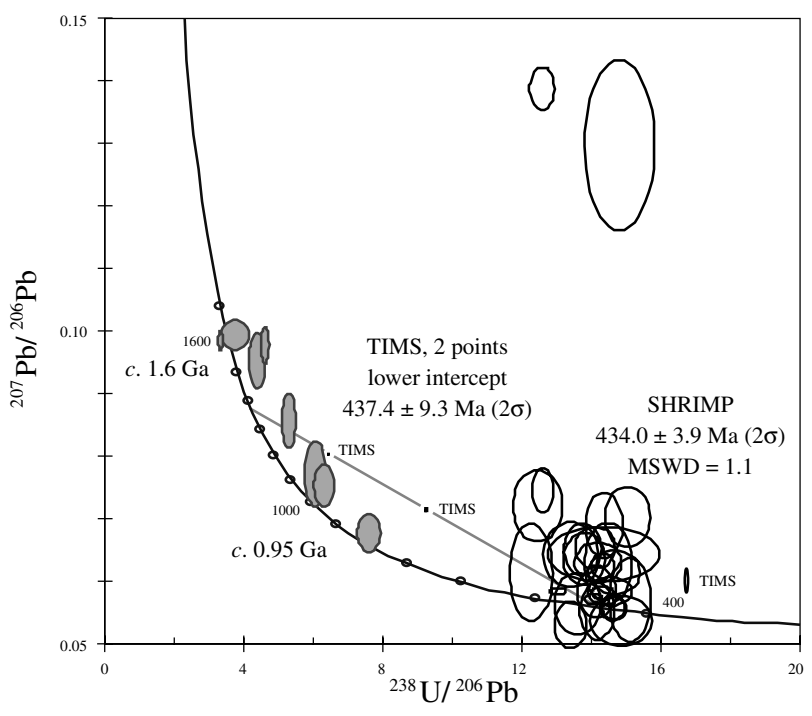

Fig. 8. Tera-Wasserburg diagram of $\mathrm{U} / \mathrm{Pb}$ zircon analyses of the Sogneskollen granodiorite and associated dykes. SHRIMP ratios are uncorrected and shown as $\pm 1 \sigma$. Core analyses shown with filled grey ellipses. analysis; the range therefore most likely reflects Early Proterozoic grains that underwent Late Proterozoic $\mathrm{Pb}$ loss. Tectonics events of $1.75-1.45 \mathrm{Ga}$ and $1.25-$ $0.95 \mathrm{Ga}$ are known in Scandinavia as the Gothian and Sveconorwegian, respectively, and have both been identified in the southern part of the WGC immediately east of the study area (Skår, 1998). Except for one spot age of $795 \mathrm{Ma}$, which cathodoluminesence imaging suggests is the result of simultaneous analysis of two age domains, the remainder of the spot ages from the zircon rims are Palaeozoic-503-262 Ma. The three oldest Palaeozoic spot ages, 503, 489 and $482 \mathrm{Ma}$ also appear to be the result of mixing of two age domains. Twenty-one of the remaining spot ages can be pooled to form a ${ }^{207} \mathrm{~Pb}$-corrected, weighted mean ${ }^{238} \mathrm{U} /{ }^{206} \mathrm{~Pb}$ age of $434.0 \pm 3.9 \mathrm{Ma}(2 \sigma$ internal error $)$ with a good fit $($ MSWD $=1.1)$. The three separate samples have weighted mean ${ }^{238} \mathrm{U} /{ }^{206} \mathrm{~Pb}$ SHRIMP ages that are equivalent at the $95 \%$ confidence interval, and are therefore coeval at the current level of precision. Four younger Palaeozoic spot ages, 412, 407, 383 and $262 \mathrm{Ma}$, lie significantly (95\% confidence interval) outside the $434.0 \pm 3.9 \mathrm{Ma}$ population. The low $262 \mathrm{Ma}$ result is from a spot with extremely high (c. $3300 \mathrm{ppm}) \mathrm{U}$ concentration and clearly reflects significant $\mathrm{Pb}$ loss. The 412, 407 and $383 \mathrm{Ma}$ results 
are from spots with low $\mathrm{U}$ concentrations: $c .78,61$ and 42 p.p.m., respectively. $\mathrm{Pb}$ loss associated with radiation-induced lattice damage is a less attractive option to explain these results and perhaps they reflect very thin overgrown rims at c. $400 \mathrm{Ma}$. Considering all the results, c. $434 \mathrm{Ma}$ is interpreted as the crystallization age of the magma and the younger Palaeozoic spot ages as the result of $\mathrm{Pb}$ loss and/or later overgrowths, It is possible, however, that the $434 \mathrm{Ma}$ age includes inherited grains.

The age of metamorphism in the Solund-HyllestadLavik area has been partly constrained by Chauvet \& Dallmeyer (1992), who dated four muscovite and two hornblende (Fig. 3a). Two of the four muscovite yielded well-behaved spectra with ages of $398.5 \pm 0.3$ and $394.3 \pm 0.3 \mathrm{Ma}$ (our recalculations); the other two spectra show serially increasing or decreasing step ages for which we take weighted mean ages of c. $403 \pm 3 \mathrm{Ma}$. The muscovite ages may decrease with structural depth (Fig. 3b) - a progression typical of muscovite ${ }^{40} \mathrm{Ar} /{ }^{39} \mathrm{Ar}$ ages within the NSDZ (Andersen, 1998; Boundy et al., 1996; Chauvet \& Dallmeyer, 1992; Eide et al., 1997); they indicate that the amphibolite facies extension along the NSDZ was over by $403 \mathrm{Ma}$. The two hornblende ages of Chauvet \& Dallmeyer (1992), c. $395.9 \pm 1.1 \mathrm{Ma}$ and c. $409 \pm 3 \mathrm{Ma}$, are systematically older than muscovite from the same localities by $2-4 \mathrm{Ma}$.

There are presently no radiometric ages on the eclogites in the Lavik area, so, we provisionally assume that the Lavik eclogites formed during the c. 410400 (?) Ma HP event in the WGC (Lutro et al., 1997; Mearns, 1986; Mørk \& Mearns, 1986; Root et al., 2000; Terry et al., 2000) because the Lavik eclogites are part of this complex.

\section{DISCUSSION}

An important finding from our study is that E-directed thrusting recorded in the dyke swarm at the base of the Sogneskollen granodiorite finished after $434 \pm 4 \mathrm{Ma}$, and that major top-W extension at amphibolite facies conditions developed subsequently. As implied above, igneous rocks similar in age to the Sogneskollen granodiorite are widespread in the Uppermost and Upper Allochthons. These bodies include, for example, the Bindal Batholith $(430 \pm 7-$ $447 \pm 7 \mathrm{Ma} \mathrm{U} / \mathrm{Pb}$ zircon ages, Nordgulen et al., 1993) and the Smøla-Hitra Batholith (c. 435 Ma $\mathrm{U} / \mathrm{Pb}$ zircon, Nordgulen et al., 1995). In western Norway, the Sunnhordland Batholith $(\mathrm{Rb} / \mathrm{Sr}$ c. $430 \mathrm{Ma}$, Andersen \& Jansen, 1987; Fossen \& Austrheim, 1988), the Bremanger Granodiorite and the Gåsøy diorite $(\mathrm{U} / \mathrm{Pb}$ zircon $440 \pm 5 \mathrm{Ma}$, Hansen et al., 2001) are arc plutons intruding ophiolites, arc volcanic rocks and olistostromes. Thus, the relationships observed in the Hyllestad area - a granodiorite intruding oceanic rocks and their sedimentary cover, but not the structurally lower continental rocks-are typical of this suite of broadly Llandoverian to Wenlockian igneous rocks, and support a correlation of the Lifjorden Complex with the oceanic nappes of the Upper Allochthon. The nearest oceanic rocks of the Upper Allochthon are the Solund-Stavfjord ophiolite, which has a $\mathrm{U} / \mathrm{Pb}$ zircon age of $443 \pm$ $3 \mathrm{Ma}$ (Dunning \& Pedersen, 1988) and is overlain by the Staveneset Group metagraywacke and arc-related metavolcanics (Furnes et al., 1990). The ophiolite probably formed near a continent, because some of the MORB sills intruded greywackes containing metamorphic rock fragments, abundant clastic quartz grains and clastic zircon of Early Proterozoic to Middle Ordovician age (Pedersen \& Dunning, 1993; Skjerlie et al., 1989). Recently, an arc rhyolite landslide block in the Devonian Solund Basin has been dated at $439 \pm 1 \mathrm{Ma}$ (Hartz et al., in press), and unpublished $\mathrm{U} / \mathrm{Pb}$ data from a quartz-diorite dyke in the ophiolite suggest that the terminal magmatic stage of the ophiolite is late Llandoverian (Y. Dilek \& H. Furnes pers. com. 2001). The final stages of the ophiolite emplacement onto the continental Middle Allochthon Høyvik Group took place during deposition of the Sunnfjord obduction melange and the Herland Group, a Wenlockian passive-margin sequence (Andersen et al., 1990).

The presence of the $434 \pm 4 \mathrm{Ma}$ Sogneskollen granodiorite within oceanic rocks correlated with the Solund-Stavfjord ophiolite does not conflict with the Wenlockian emplacement age of that ophiolite (Fig. 2). Whether the top-E deformation recorded in the Sogneskollen granodiorite can be correlated with the Wenlockian emplacement age of the SolundStavfjord ophiolite is, however, an open question. There are at least two possible scenarios that can explain the geological observations: (1) While the base of the Wenlockian is quoted as $428 \mathrm{Ma}$, the actual radiochronologic constraint is $=430.1 \pm$ $2.4 \mathrm{Ma}$ (Tucker \& McKerrow, 1995). This age is indistinguishable from $434 \pm 4 \mathrm{Ma}$ at the $95 \%$ confidence interval, and thus, the top-E displacement in the Solund-Hyllestad-Lavik area could be temporally and kinematically equivalent to emplacement of the Solund-Stavfjord ophiolite, but it must have taken place in the earliest Wenlockian. (2) The crystallization age we report for the Sogneskollen granodiorite may be wrong. As discussed above, at the current level of precision, nearly all of the SHRIMP rim ages form a single population but the spread of rim ages is large enough that higher precision analyses might reveal more than one population within the cluster.

\section{BURIAL AND EXHUMATION OF THE HP ROCKS}

We infer the following tectonic history for the study area (Fig. 9). (1) The Hyllestad Complex was deposited on the WGC; it could possibly be as young as Wenlockian if it is part of the Lower Allochthon, 
$428 \mathrm{Ma}$ (base of the Wenlockian): convergence rate $8-12 \mathrm{~cm} / \mathrm{a}$

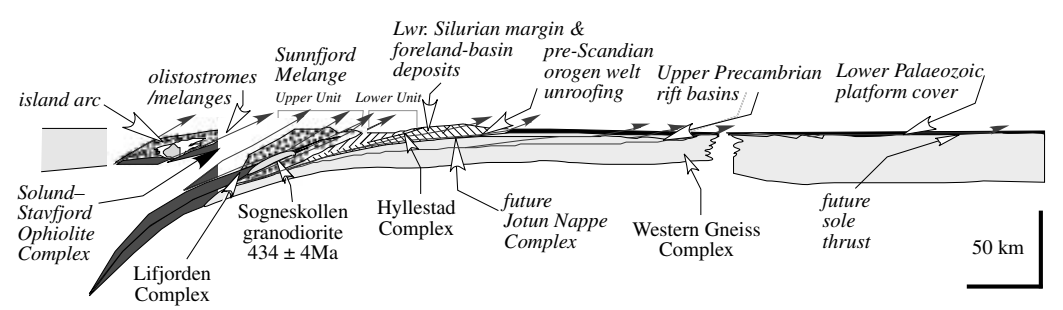

410 Ma Early Devonian: subduction of WGC \& onset of extension at high structural levels
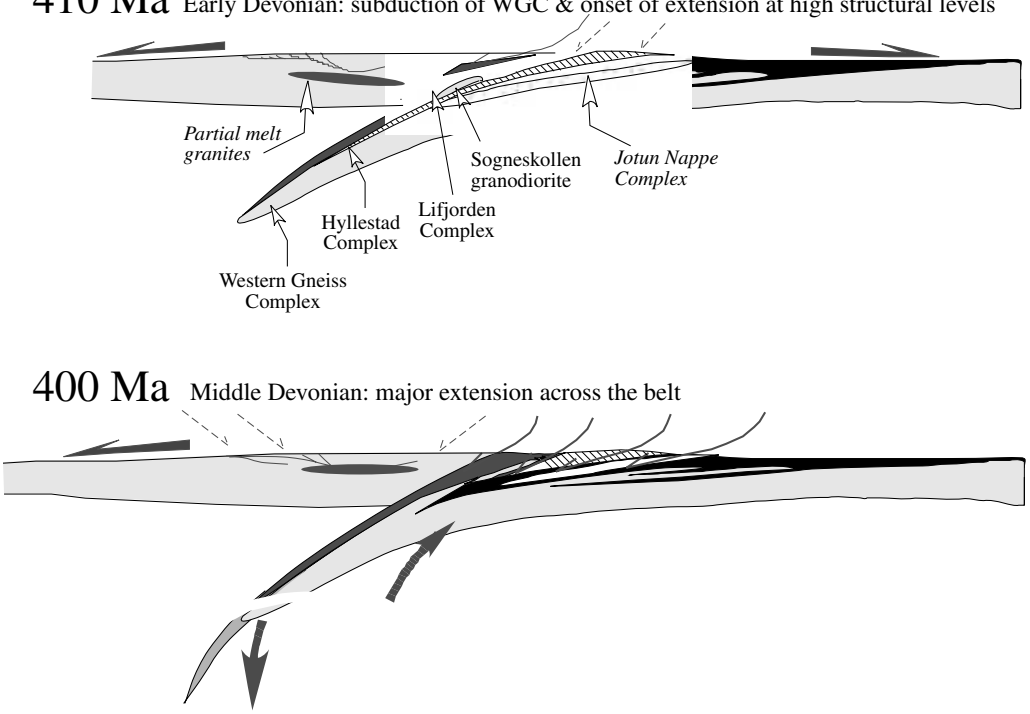

Fig. 9. Tectonic evolution of western Norway. Following crystallization of Sogneskollen granodiorite at c. $434 \mathrm{Ma}$, Upper Allochthon emplaced onto lower units around c. $428 \mathrm{Ma}$. Lower Allochthon and WGC subducted to high pressures at c. $410 \mathrm{Ma}$. Major exhumation finished by c. $400 \mathrm{Ma}$. and likely experienced a $c .447$ Ma metamorphism if it is part of the Middle Allochthon Høyvik Group. (2) The Lifjorden Complex formed as part of the Upper Allochthon (chiefly as sediments deposited on mafic crust) and then was intruded by the $434 \mathrm{Ma}$ Sogneskollen granodiorite. (3) The Lifjorden Complex was thrust eastward over the Hyllestad Complex soon thereafter-likely extending into the Wenlockian-and imprinting minor top-E structures in both units. (4) At c. 410-400 (?) Ma, the WGC was subducted to $80 \mathrm{~km}$ depth, forming the Lavik eclogites; the Hyllestad Complex was buried/subducted to $50 \mathrm{~km}$ depth, metamorphosing the highly aluminous schists; and the Lifjorden Complex was buried to $30 \mathrm{~km}$ depth. (5) By $403 \mathrm{Ma}$, when muscovite within the WGC closed to Ar loss (Chauvet \& Dallmeyer, 1992), the 0.7-0.9 GPa metamorphism common to all the units in the Solund-Hyllestad-Lavik area occurred. This implies that, by that time, the WGC and Hyllestad Complex were exhumed c. $50 \mathrm{~km}$ and c. $20 \mathrm{~km}$ vertically by the NSDZ, respectively. This exhumation corresponds to a normal displacement of $70-110 \mathrm{~km}$ depending on the synkinematic dip (40$25^{\circ}$ ) of the NSDZ (present dip $c .25^{\circ}$ ). While $70 \mathrm{~km}$ of normal displacement is compatible with the integrated shear strain calculated from strain measurements in the c. $2-3 \mathrm{~km}$ thick NSDZ in the Sunnfjord area (Hveding, 1992), the $110 \mathrm{~km}$ estimate based on the present orientation of the shear zone may be too high, because of the asymmetrical uplift that accompanied the denudation of the mountain belt in western Norway. (6) At an unknown later time, the Solund fault juxtaposed the c. $0.4 \mathrm{GPa}$ sillimanite-stable overprint of the Hyllestad Complex against the prehnite-pumpellyite facies Solund Conglomerate $(=0.3 \mathrm{GPa})$ - only a few $\mathrm{km}$ of exhumation.

\section{CONCLUSIONS}

Geological field relations, combined with thermobarometry, structural petrology and geochronology, document that the geological history of the SolundHyllestad-Lavik area involved (i) intrusion of $434 \mathrm{Ma}$ granodiorite into oceanic rocks; (ii) emplacement of those rocks over continental margin sediments; (iii) subduction of the continental margin sediments to $50 \mathrm{~km}$ and the underlying continental crystalline rocks to $80 \mathrm{~km}$; and (iv) exhumation and attenuation of the entire sequence by normal-sense motion along the 
Nordfjord-Sogn detachment zone by $403 \mathrm{Ma}$. These observations solidify our understanding of the timing and nature of the cycle of ophiolite emplacement, continental subduction and large-scale exhumation that appears to typify the Caledonian history of western Norway.

\section{ACKNOWLEDGEMENTS}

Physics of Geological Processes publication no. 13. Supported by NSF grant EAR-9814889 and the Physics of Geological Processes Center, University of Oslo. Helpful reviews were given by $\mathrm{H}$. Brueckner and S. Cuthbert. Some of the samples and data were collected by A. Vasquez.

\section{SUPPLEMENTARY MATERIAL}

Tables S1 and S2 are available for downloading from http://www.blackwellpublishing.com/products/journals/ suppmat/JMG/JMG468/JMG468sm.htm.

\section{REFERENCES}

Andersen, T. B., 1998. Extensional tectonics in the Caledonides of southern Norway, an overview. Tectonophysics, 285, 333351.

Andersen, T. B. \& Andresen, A., 1994. Stratigraphy, tectonostratigraphy and the accretion of outboard terranes in the Caledonides of Sunnhordland, W. Norway. Tectonophysics, 231, 71-84.

Andersen, T. B., Berry, H. N., Lux, D. R. \& Andresen, A., 1998. The tectonic significance of pre-Scandian ${ }^{40} \mathrm{Ar} /{ }^{39} \mathrm{Ar}$ phengite cooling ages from the Caledonides of western Norway. Journal of the Geological Society of London, 155, 297-309.

Andersen, T. B. \& Jamtveit, B., 1990. Uplift of deep crust during orogenic extensional collapse: a model based on field studies in the Sogn-Sunnfjord region of western Norway. Tectonics, 9, $1097-1111$.

Andersen, T. B. \& Jansen, Ø. J., 1987. The Sunnhordland Batholith, W. Norway; regional setting and internal structures, with emphasis on the granitoid plutons. Norsk Geologisk Tidsskrift, 67, 159-183.

Andersen, T. B., Osmundsen, P. T. \& Jolivet, L., 1994. Deep crustal fabrics and a model for the extensional collapse of the southwest Norwegian Caledonides. Journal of Structural Geology, 16, 1191-1203.

Andersen, T. B., Skjerlie, K. P. \& Furnes, H., 1990. The Sunnfjord Melange, evidence of Silurian ophiolite accretion in the West Norwegian Caledonides. Journal of the Geological Society of London, 147, 59-68.

Austrheim, H., 1990. Fluid-induced processes in the lower crust as evidenced by Caledonian eclogitization of Precambrian granulites, Bergen Arcs, Western Norway. PhD Thesis, University of Oslo, Oslo.

Bassett, M. G., 1985. Silurian stratigraphy and facies development in Scandinavia. In: The Caledonide Orogen-Scandinavia and Related Areas (eds Gee, D. G. \& Sturt, B. A.), pp. 283292. John Wiley and Sons, Chichester.

Bockelie, J. F. \& Nystuen, J. P., 1985. The southeastern part of the Scandinavian Caledonides. In: The Caledonide OrogenScandinavia and Related Areas (eds Gee, D. G. \& Sturt, B. A.), pp. 69-88. John Wiley and Sons, Chichester.

Boundy, T. M., Essene, E. J., Hall, C. M., Austrheim, H. \& Halliday, A. N., 1996. Rapid exhumation of the lower crust during continent-continent collision and late extension: Evidence from ${ }^{40} \mathrm{Ar} /{ }^{39} \mathrm{Ar}$ incremental heating of hornblendes and muscovites, Caledonian orogen, western Norway. Geological Society of America Bulletin, 108, 1425-1437.

Brekke, H. \& Solberg, P. O., 1987. The geology of Atløy, Sunnfjord western Norway. Norges Geologiske Undersøkelse Bulletin, 410, 73-94.

Carswell, D. A., Wilson, R. N. \& Zhai, M., 2000. Metamorphic evolution, mineral chemistry and thermobarometry of schists and orthogneisses hosting ultra-high pressure eclogites in the Dabieshan of central China. Lithos, 52, 121-155.

Chauvet, A. \& Brunel, M., 1988. La grande faille normale ductile du Sunnfjord; Une extension NW-SE dans la chaine caledonienne de l'Ouest Norvege. Comptes Rendus de L'academie des Sciences, Serie 2, Mecanique, Physique, Chimie, Sciences de L'university, Sciences de la Terre, 307, 415-422.

Chauvet, A. \& Dallmeyer, R. D., 1992. ${ }^{40} \mathrm{Ar} /{ }^{39} \mathrm{Ar}$ mineral dates related to Devonian extension in the southwestern Scandinavian Caledonides. Tectonophysics, 210, 155-177.

Chauvet, A., Kienast, J. R., Pinardon, J. L. \& Brunel, M., 1992. Petrological constraints and PT path of Devonian collapse tectonics within the Scandian mountain belt (Western Gneiss Region, Norway). Journal of the Geological Society of London, 149, 383-400.

Chauvet, A. \& Séranne, M., 1989. Microtectonic evidence of Devonian extensional westward shearing in southern Norway. In: The Caledonide Geology of Scandinavia (ed. Gayer, R. A.), pp. 245-254. Graham and Trotman, London.

Cuthbert, S. J., 1991. Evolution of the Devonian Hornelen Basin, west Norway: new constraints from petrological studies of metamorphic clasts. In: Developments in Sedimentary Provenance Studies, Special Publication 57 (eds Morton, A. C., Todd, S. P. \& Haughton, P. D. W.), pp. 343-360, Geological Society, London.

Cuthbert, S. J., Carswell, D. A., Krogh-Ravna, E. J. \& Wain, A., 2000. Eclogites and eclogites in the Western Gneiss Region, Norwegian Caledonides. Lithos, 52, 165-195.

Dewey, J. F., Ryan, P. D. \& Andersen, T. B., 1993. Orogenic uplift and collapse, crustal thickness, fabrics and metamorphic phase changes. In: Magmatic Processes and Plate Tectonics, Special Publication 76 (eds Prichard, H. M., Alabaster, T., Harris, N. B. W. \& Neary, C. R.), pp. 325-343. Geological Society, London.

Dunning, G. R. \& Pedersen, R. B., 1988. U/Pb ages of ophiolites and arc-related plutons of the Norwegian Caledonides: implications for the development of Iapetus. Contributions to Mineralogy and Petrology, 98, 13-23.

Florence, F. P. \& Spear, F. S., 1991. Effects of diffusional modification of garnet growth zoning on P-T path calculations. Contributions to Mineralogy and Petrology, 107, 487-500.

Fossen, H. \& Austrheim, H., 1988. Age of the Krossnes Granite, west Norway. Norges Geologiske Undersøkelse Bulletin, 413, 61-65.

Furnes, H., Skjerlie, K. P., Pedersen, R. B., Andersen, T. B., Stillman, C. J., Suthren, R., Tysseland, M. \& Garman, L. B., 1990. The Solund-Stavfjord ophiolite complex and associated rocks, west Norwegian Caledonides: Geology, geochemistry and tectonics environment. Geological Magazine, 127, 209-224.

Gee, D. G., Lobkowicz, M. \& Singh, S., 1994. Late Caledonian extension in the Scandinavian Caledonides - the Røragen detachment revisited. Tectonophysics, 231, 139-155.

Gee, D. G. \& Zachrisson, E., 1979. The Caledonides in Sweden. Sveriges Geologiska Undersökning, C769, 48.

Greiling, R. O., Garfunkel, Z. \& Zachrisson, E., 1998. The orogenic wedge in the central Scandinavian Caledonides: Scandian structural evolution and possible influence on the foreland basin. Geologiska Föreningens I Stockholm Förhandlingar, 120, 181-190.

Griffin, W. L. \& Brueckner, H. K., 1980. Caledonian Sm-Nd ages and a crustal origin for Norwegian eclogites. Nature, 285, 319-321. 
Hansen, J., Skjerlie, K. P., Pedersen, R. B. \& Rosa, J., 2001. Age and petrogenesis of the Bremanger granitoid complex, west Norwegian Caledonides. Geonytt (Abstract), 28, 57.

Hartz, H. H., Martin, M. W., Andresen, A. \& Andersen, T. B., in press. Volcanic rocks in the Devonian Solund Basin, Western Norway: large landslides of Silurian (439 Ma) rhyolites. Journal of the Geological Society of London, in press.

Hossack, J. R., Garton, M. R. \& Nickelsen, R. P., 1985. The geological section from the foreland up to the Jotun thrust sheet in the Valdres area, south Norway. In: The Caledonide Orogen - Scandinavia and Related Areas (eds Gee, D. G. \& Sturt, B. A.), pp. 443-456. John Wiley \& Sons, Chichester.

Hveding, B., 1992. Structural geology of the mylonites below the Dalsfjord Fault, Atløy-Askvoll area, Sunnfjord, Western Norway. Cand. Scient. Thesis (in Norwegian), University of Oslo, Oslo.

Kamb, W. B., 1959. Ice petrofabric observations from Blue Glacier, Washington, in relation to theory and experiment. Journal of Geophysical Research, 66, 259-271.

Lutro, O., Robinson, P., Solli, A., Tucker, R. D., Wain, A., Terry, M. P. \& Krabbendam, M., 1997. Proterozoic geology and Scandian high-pressure overprinting in the Western Gneiss Region. Norges Geologiske Undersokelse Report, 132, $1-86$.

Mearns, E. W., 1986. Sm-Nd ages for Norwegian garnet peridotite. Lithos, 19, 269-278.

Milnes, A. G., Wennberg, O. P., Skår, Ø. \& Koestler, A. G., 1997. Contraction, extension, and timing in the South Norwegian Caledonides: the Sognefjord transect. In: Orogeny Through Time, Special Publication, 121, (eds Burg, J.-P. \& Ford, M.), pp. 123-148. Geological Society, London.

Mørk, M. B. E. \& Mearns, E. W., 1986. Sm-Nd isotopic systematics of a gabbro-eclogite transition. Lithos, 19, 255267.

Nilsen, T. H., 1968. The relationship of sedimentation to tectonics in the Solund Devonian District of southwestern Norway. Norges Geologiske Undersøkelse Bulletin, 259, $1-108$.

Nordgulen, Ø., Bickford, M. E., Nissen, A. L. \& Wortman, G. L., 1993. U-Pb zircon ages from the Bindal Batholith, and the tectonic history of the Helgeland Nappe Complex, Scandinavian Caledonides. Journal of the Geological Society of London, 150, 771-783.

Nordgulen, Ø., Solli, A. \& Sundvoll, B., 1995. Caledonian granitoids in the Frøya-Froan area. Norges Geologiske Undersokelse Bulletin, 427, 48-51.

Norton, M. G., 1986. Late Caledonide extension in western Norway: a response to extreme crustal thickening. Tectonics, 5, 195-204.

Norton, M. G., 1987. The Nordfjord-Sogn detachment, W. Norway. Norsk Geologisk Tidsskrift, 67, 93-106.

Norton, M. G., McClay, K. R. \& Way, N. A., 1987. Tectonic evolution of Devonian basins in northern Scotland and southern Norway. Norsk Geologisk Tidsskrift, 67, 323-338.

Osmundsen, P. T. \& Andersen, T. B., 1994. Caledonian compressional and late-orogenic extensional deformation in the Staveneset area, Sunnfjord, Western Norway. Journal of Structural Geology, 16, 1385-1401.

Osmundsen, P. T. \& Andersen, T. B., 2001. The middle Devonian basins of western Norway: sedimentary response to large-scale transtensional tectonics? Tectonophysics, 332, $51-68$.

Osmundsen, P. T., Andersen, T. B., Markussen, S. \& Svendby, A. K., 1998. Tectonics and sedimentation in the hanging wall of a major extensional detachment: the Devonian Kvamshesten Basin, western Norway. Basin Research, 10, 213-234.

Pedersen, R. B., Bruton, D. L. \& Furnes, H., 1992. Ordovician faunas, island-arcs and ophiolites in the Scandinavian Caledonides. Terra Nova, 4, 217-222.
Pedersen, R. B. \& Dunning, G. R., 1993. Provenance of turbiditic cover to the Caledonian Solund Stavfjord Ophiolite from $\mathrm{U}-\mathrm{Pb}$ single zircon dating. Journal of the Geological Society of London, 150, 673-676.

Powell, R. \& Holland, T. J. B., 1988. An internally consistent dataset with uncertainties and correlations: 3 . Applications to geobarometry, worked examples and a computer program. Journal of Metamorphic Geology, 6, 173-204.

Ratschbacher, L., Sperner, B., Meschede, M. \& Frisch, W., 1994. Computer techniques and applications: a program library for quantitative structural analysis. Tübinger Geowissenschaftliche Arbeiten, 21, 1-73.

Roberts, D. \& Gee, D. G., 1985. An introduction to the structure of the Scandinavian Caledonides. In: The Caledonide OrogenScandinavia and Related Areas (eds Gee, D. G. \& Sturt, B. A.), pp. 55-68. John Wiley and Sons, Chichester.

Root, D. B., Hacker, B. R. \& Mattinson, J. M., 2000. Exhumation of Norwegian UHP eclogites. III. Expansion of the UHP terrane and $\mathrm{U} / \mathrm{Pb}$ zircon ages of synorogenic plutonic rocks. Geological Society of America Abstracts with Programs, 32, A236.

Schmid, S. M. \& Casey, M., 1986. Complete fabric analysis of some commonly observed quartz c-axis patterns. Geophysical Monograph, 36, 263-286.

Séguret, M., Séranne, M., Chauvet, A. \& Brunel, M., 1989. Collapse basin: a new type of extensional sedimentary basin from the Devonian of Norway. Geology, 17, 127-130.

Séranne, M. \& Séguret, M., 1987. The Devonian basins of western Norway: Tectonics and kinematics of extending crust. Geological Society of London Special Publication, 28, 537-548.

Siedlecka, A., 1975. Old Red Sandstone lithostratigraphy and sedimentation of the Outer Fosen area, Trondheim region. Norges Geologiske Undersøkelse, 321, 1-35.

Skår, Ø., 1998. The Proterozoic and Early Palaeozoic evolution of the southern part of the Western Gneiss Complex, Norway. Dr. scient. Thesis, University of Bergen, Norway.

Skjerlie, K. P., Furnes, H. \& Johansen, R., 1989. Magmatic development and tectono-magmatic models for the SolundStavfjorden Ophiolite Complex, W. Norwegian Caledonides. Lithos, 23, 137-151.

Skjerlie, K. P., Pedersen, R. B., Wennberg, O. P. \& de la Rosa, J., 2000. Volatile-phase fluxed anatexis of metasediments during late Caledonian ophiolite obduction: evidence from the Sogneskollen Granitic Complex, west Norway. Journal of the Geological Society of London, 157, 1199-1213.

Soper, N. J., Strachan, R. A., Holdsworth, R. W., Gayer, R. A. \& Greiling, R. O., 1992. Sinistral transpression and the Silurian closure of Iapetus. Journal of the Geological Society of London, 149, 871-880.

Spear, F. \& Menard, T., 1989. Program GIBBS: a generalized Gibbs method algorithm. American Mineralogist, 74, 942-943.

Steel, R. J., Siedlicka, A. \& Roberts, D., 1985. The Old Red Sandstone basins of Norway and their deformation: a review. In: The Caledonide Orogen-Scandinavia and Related Areas (eds Gee, D. G. \& Sturt, B. A.), pp. 293-316. John Wiley and Sons, Chichester.

Stephens, M. B. \& Gee, D. G., 1985. A tectonic model for the evolution of the eugeoclinal terranes in the central Scandinavian Caledonides. In: The Caledonide Orogen-Scandinavia and Related Areas (eds Gee, D. G. \& Sturt, B. A.), pp. 953-978. John Wiley and Sons, Chichester.

Sturt, B. A., Ramsay, D. M. \& Neuman, R. B., 1991. The Otta Conglomerate, the Vågåmo Ophiolite - further indications of early Ordovician orogenesis in the Scandinavian Caledonides. Norsk Geologisk Tidsskrift, 71, 107-115.

Swensson, E. \& Anderson, T. B., 1991. Contact relationships between the Askvoll group and the basement gneisses of the Western Gneiss Region (WGR), Sunnfjord, Western Norway. Norsk Geologisk Tidsskrift, 71, 15-27.

Terry, M. P., Robinson, P., Hamilton, M. A. \& Jercinovic, M. J., 2000. Monazite geochronology of UHP and HP metamorphism, deformation, and exhumation, Nordøyane, Western 
Gneiss Region, Norway. American Mineralogist, 85, 16511664.

Tillung, M., 1999. Structural and Metamorphic Development of the Hyllestad-Lifjorden Area, Western Norway. Cand. Scient. Thesis, University of Bergen, Bergen.

Torsvik, T. H., 1998. Palaeozoic palaeogeography: a North Atlantic viewpoint. Geologiska Föreningens I Stockholm Förhandlingar, 120, 109-118.

Tucker, R. D., Bradley, D. C., Straeten, C. A. V., Harris, A. G., Ebert, J. R. \& McCutcheon, S. R., 1998. New U-Pb zircon ages and the duration and division of Devonian time. Earth and Planetary Science Letters, 158, 175-186.
Tucker, R. D. \& McKerrow, W. S., 1995. Early Paleozoic chronology: a review in light of new U-Pb zircon ages from Newfoundland and Britain. Canadian Journal of Earth Sciences, 32, 368-379.

Wain, A., Waters,D., Jephcoat,A. \& Olijnyk, H.,2000. The highpressure to ultrahigh-pressure transition in the Western Gneiss Region, Norway. European Journal of Mineralogy, 12, 667-687.

Received 14 February 2002; revision accepted 21 August 2002. 